\title{
In search of stock repurchases determinants in listed Indonesian firms during regulatory changes
}

\author{
Abdul Moin \\ Faculty of Economics, Islamic University of Indonesia, Indonesia \\ abdul.moin@uii.ac.id \\ Yilmaz Guney \\ Business School, University of Hull, UK \\ y.guney@hull.ac.uk \\ Izidin El Kalak \\ Business School, Cardiff University, UK \\ elkalaki@cardiff.ac.uk
}

\section{Citation of this paper:}

Moin, A., Guney, Y. and El Kalak, I. (2020). In search of stock repurchases determinants in listed Indonesian firms during regulatory changes, Journal of Economic Behavior \& Organization, forthcoming. 


\title{
In search of stock repurchases determinants in listed Indonesian firms during regulatory changes
}

\begin{abstract}
Motivated by the introduction of share repurchases regulations in 1998 and 2007 coupled with unique characteristics of the Indonesian market, we investigate the effect of firms' sub-optimal financial position on their share repurchases decisions. Then, we study the effect of these determinants through an exogenous shock, the 2007 regulatory change. We show that suboptimal financial positions play a role in the corporate share repurchases decisions. Further, we find that the enactment of the regulations has a significant effect on firms' undertaking share repurchases programs. Unlike the common perception and findings in the literature, we observe that the underpricing of shares has a weak effect on the Indonesian firms' decisions to repurchase their stocks. Our results hold using several estimation methods that account for potential endogeneity issues.
\end{abstract}

Keywords: share repurchases; regulations; dividends; sub-optimal decisions; underpricing; Indonesia.

JEL classification: G32, G35 


\section{Introduction}

In the last two decades, the increasing number of firms undertaking stock repurchases and the fast-growing intensity of cash used to repurchase shares have been important issues in corporate finance (Weigand and Baker, 2009; Lee and Suh, 2011). The increasing number of firms conducting share buybacks occurred not only in the U.S.A. but also all over the world (Baker et al., 2010). This phenomenon, particularly outside the U.S.A., was induced by regulatory changes in many countries in the 1990s which significantly affected the propensity of public firms to repurchase their own stocks (Manconi et al., 2018). Since the 1990s, several AsiaPacific countries ${ }^{1}$ have enacted share repurchases regulations to avoid the declining prices of firms' stocks due to the impact of future unfavorable financial conditions driven by the U.S. capital market crashes in 1987 and 1989 (DeAngelo et al., 2004).

Regulators argue that the regulations aim to reduce agency problems and prevent abusive market practices (Leuz and Wysocki, 2016; Fauver et al., 2017). Therefore, several studies were conducted to test their effects. The findings are inconclusive. On one hand, some studies suggest that the enactment of regulations has positive effects not only for capital market performance but also for the improvement of individual firms (Fauver et al., 2017). On the other hand, the effectiveness and benefits of the regulations on capital markets are still subject to long-standing debate due to further impacts and consequences including the existence of externalities and economy-wide cost (Leuz and Wysocki, 2016).

In this study, we focus our analysis in the context of a single large emerging economy, more specifically, the Indonesian market. First, we investigate the determinants of share repurchases among Indonesian Stock Exchange (IDX) listed firms after the introduction of the first regulatory changes in 1998. Then, we investigate the effect of the second regulatory

\footnotetext{
${ }^{1}$ New regulatory changes in share repurchases were implemented in Australia in 1989, Hong Kong in 1991, Korea and New Zealand in 1994, Japan in 1995, Malaysia in 1997, and Indonesia in 1998 and 2007.
} 
changes in 2007, as an exogenous shock, on the intensity of share repurchases policies. In addition, we examine the relationship between the firms' decisions to deviate from their optimal corporate policies, i.e., excess cash holdings, paying excess dividends, and holding lower than optimal leverage and the firms' share repurchases policies. Finally, we test for an association between share repurchases and firms' corporate governance mechanisms.

As one of the fastest growing capital markets in Asia, Indonesian listed firms have been extensively carrying out share repurchases programmes since the first regulation in 1998 and particularly after the enactment of the share repurchases regulation in 2007. As for the Indonesian regulators, the primary objectives of these regulations were to: (i) anticipate the declining price of firms' stocks due to market instability stemming from the impact of the capital market crashes in 1989 and the global financial crisis of 2008; (ii) foster stock market activities through which individual firms can offer premium prices that may attract shareholders selling their stocks; (iii) regain investors' confidence in the future prospects of firms. Motivated by these regulatory changes concerning share repurchases coupled with the unique characteristics of the Indonesian market, ${ }^{2}$ we chose to unearth the main determinants of share repurchases in Indonesia and study the impact of the regulations on the firms' decisions to buy back shares.

Theoretically, several motives have been proposed to justify the firms' share repurchases decisions. ${ }^{3}$ These motives are mainly justified from the perspective of developed countries with established economies. However, they do not necessarily hold for emerging countries and they may well vary from one country to another. To provide further evidence, several studies have been conducted using international or emerging country-specific samples.

\footnotetext{
${ }^{2}$ See Duygun et al. (2018) and Moin et al. (2019) for more details on the main characteristics on the Indonesian market.

${ }^{3}$ Some of the main motives are: agency motive (Jensen, 1986); market timing due to undervaluation of stocks (Massa et al., 2007; Chan et al., 2010); excess capital motive (Dittmar, 2000); signaling motive (Grullon and Michaely, 2004); overinvestment motive (Boudry et al., 2013).
} 
For example, Faccio et al. (2001) study the expropriation effect of outside shareholders by controlling shareholders using a sample of Western European and East Asian firms. To test this effect, they focus on the firms' dividend policies. They find that East Asian firms distribute lower dividend rates compared to Western European firms, which suggests that firms operating under weak legal shareholder protection are more likely to suffer from expropriation by large shareholders. Furthermore, Byrne and O'Connor (2017) examine how creditors affect dividend payouts in various disclosure regimes. Using a sample of firms from 28 countries, they find that poorly-protected creditors do not restrict the practice by firms in opaque regimes of using large dividend payouts to build reputation capital, and place few restrictions on dividend payouts in transparent regimes. Mulyani et al. (2016) examine the role dividends and leverage in reducing the agency conflict arising from the dominance of family-controlled firms in the Indonesian market. Furthermore, Moin et al. (2019) investigate the association between corporate ownership structure and cash dividends using a sample of Indonesian listed firms. They also confirm the expropriation hypothesis that minority interests are put at risk by large shareholders.

In more related share repurchases literature, Cheng and Hou (2013), on a microstructure level, use the information disclosures of open-market repurchases in Taiwan to test the association between the firm's share repurchases announcements and the market responses to these announcements. They find that the intention ratio, defined as the ratio of the number of shares intended to be repurchased to the number of outstanding shares, leads to a higher market reaction within a two-day announcement effect. Using data from Hong Kong, Firth et al. (2010) find some evidence consistent with the free cash flow and signaling arguments for share repurchases. They also examine directors' dealing activities around share repurchases periods and find a significant insider trading activity before the share repurchases period. In addition, Manconi et al. (2018) utilize a wide international sample of 31 non-U.S. countries (including 
Indonesia) to test the link between share repurchases and the firm's short- and long-term excess returns. They find that share repurchases increase the firms' long- and short-term excess returns. We further extend this literature by focusing our study on a single emerging market context, namely Indonesia. We test several motives behind the firms' policies to buy back shares and examine the effect of the regulatory changes on these motives and the firms' intensity to repurchase their shares.

To test our empirical predictions, we use a sample that contains 5,386 firm-year observations representing 385 unique Indonesian listed firms spanning from 1998 to 2014 . We use four estimation methods to answer our empirical questions. First, a probit regression model and marginal effects are used to analyze the propensity of firms to repurchase shares. Second, robust OLS regression models are used to analyze the intensity of firms' shares repurchases. Third, to overcome endogeneity issues and sample selection bias, we provide several robustness tests using fixed effects and IV-GMM estimation methods and Heckman two-step procedure. Fourth, the difference-in-differences (DiD) analysis is used to analyze the impact of governmental regulations on the intensity of firms undertaking share repurchases.

Our empirical results provide several findings. Overall, we find that the introduction of the 2007 regulations had a significant impact on the IDX firms to undertake share repurchases. The implementation of the regulations changed the motives behind the firms to buy back their shares. For example, before the regulation introduction in 2007 , there was a substitutional relationship between dividends and share repurchases. However, after the regulations, it became a complementary relationship. Furthermore, the excess cash and excess payout policies become significant determinants of the firms' share repurchases only after the regulatory changes in 2007. This supports the agency cost of free cash flow, whereby shareholders require a larger distribution of firms' cash rather than it being retained by managers. Conversely, the motive to capital restructuring was significant before the implementation of these regulations 
and became insignificant after that. Unlike the common perception in Indonesia, we find that shares underpricing has a weak effect on the firms' decisions to repurchase their stocks. Finally, on a corporate governance level, this study fails to support the hypothesis that firms with a larger independent board member, as a proxy for better corporate governance quality, pay more to repurchase shares. One possible explanation is that corporate governance mechanisms have not been effectively applied by IDX firms.

Another explanation could be driven by the large number of State-Owned Enterprises (SOEs) among IDX firms. Typically, the composition of the board of directors in SOEs is heavily determined by the Indonesian government. This means that the role of the board of directors is weak and the firms' strategic decisions are under the control of the government. In 1998, the Indonesian government declared its intention to regain its stock ownership from foreign and private shareholders via share buybacks. For example, the Indonesian Government through the Ministry of SOEs spent 4 trillion rupiahs (USD250 million) to repurchase $20 \%$ of SOEs stocks during the global financial crisis in 2008.

On the other hand, this study finds evidence that the higher the proportion of stocks held by institutional investors, the larger are the stock repurchases. One explanation for this is that institutional investors, as main shareholders, have strategic long-term plans to increase the percentage of ownership of the firms by increasing the intensity of the repurchases programs. Other minority shareholders who are interested in receiving the repurchases offering will sell their stocks and the proportion of stocks held by institutional investors increases.

The remainder of this study is organized as follows: Section 2 briefly reviews the literature and sets the main testable questions. Section 3 provides an overview of the share repurchases regulations in Indonesia. Section 4 presents the sample selection process. Section 5 presents the research design. Section 6 summarizes and interprets the findings. Section 7 
explores several robustness checks. Section 8 tests the effects of regulatory changes on share repurchases decisions. Section 9 concludes.

\section{Literature Review and Hypotheses Development}

The theories justifying the use of share repurchases are well developed in the literature. Baker et al. (2010) and Dhanani and Dhanani (2016) summarize the main theories and motivations regarding share repurchases activities according to the following: (i) signaling of undervaluation, (ii) agency cost of free cash flow, (iii) the tax hypothesis, (iv) capital structure, (v) takeover deterrence, and (vi) stock options. Rau and Stouraitis (2011) argue that firms experience five different cycles (waves) which starts by an initial public offering (IPO), followed by seasoned equity offerings (SEOs), stock and cash-financed acquisitions and share repurchases. They find that share repurchases occur at the end of the business cycle which is indicated by low and declining capital expenditure and low stock return. In addition, the findings are consistent with the undervaluation hypothesis explaining that firms undertake share repurchases when their stocks are undervalued.

\subsection{Dividends Overpayment and Share Repurchases}

In their dividend irrelevance theory, Miller and Modigliani (1961) argue that share repurchases and dividends are perfect substitutes. This explains that with funds available to distribute to shareholders, a firm can choose either to pay a cash dividend or to engage in share repurchases. As stated by the substitution hypothesis, firms with a particular amount of free cash flow are more likely to pay less dividends when they engage in share repurchases. Several studies find supporting evidence of this hypothesis such as that of Jiang et al. (2013). On the one hand, other researches find evidence that firms have gradually substituted share repurchases for dividends to distribute the firm's cash to shareholders (Grullon and Michaely, 2002; Aivazian et al., 2006; Von Eije and Megginson, 2008). In addition, Dittmar (2000) finds weak evidence that share 
repurchases are a perfect substitute for dividends. The study reveals that the relationship between dividends and share repurchases is significantly positive, suggesting that funds used to repurchase stocks are not available to pay dividends. This raises another possibility, that share repurchases and dividends are complementary. Providing a third possibility, Allen and Michaely (2003) argue that dividends and share repurchases are independent policies and noninterchangeable. To test the association between dividend overpayment and the propensity and intensity of share repurchases in Indonesia, we use Overpayment ${ }^{4}$ as a proxy for the firm's over payment of cash dividends. Given the above discussion, we propose the first hypothesis as follows:

H1. There is a positive association between dividend overpayment and the propensity to buy back shares or intensity of share repurchases.

\subsection{Overcash and Share Repurchases}

The second motivation for repurchasing shares is the availability of excess cash. Several arguments attempt to explain the effect of excess cash on share repurchases. The excess capital hypothesis explains that firms may distribute the temporary excess cash to shareholders via repurchasing shares as a more flexible way than dividends (Dittmar, 2000). Another reason to link share repurchases with excess cash is that the latter cannot be used optimally due to lack of sound investment opportunities. In addition, the free cash flow hypothesis proposes that the excess cash should be distributed to shareholders to mitigate the likelihood of managers using the firm's cash in their private interest, or investing it in unprofitable projects (the agency problems between shareholders and managers). In another type of conflict of interests, that is, between majority and minority shareholders, firms with such excess cash should distribute larger payouts to mitigate possible expropriation by controlling shareholders. Based on the

\footnotetext{
${ }^{4}$ Detailed definitions of variables are provided in the Appendix.
} 
agency theory, firms with higher free cash flow will be more likely to engage in share repurchases (Howe et al., 1992; Chan et al., 2004). Similarly, Jiraporn and Ning (2006) argue that firms with weak shareholder rights are able to retain more free cash within the firms, but those firms tend to repurchase fewer stocks. To test the association between the availability of excess cash and the propensity and intensity of share repurchases in Indonesia, we use Overcash as a proxy for the firm's excess cash. Based on the above arguments and in line with the free cash flow hypothesis, we posit that:

H2. There is a positive association between excess cash and the propensity to buy back shares or intensity of share repurchases.

\subsection{Underleverage and Share Repurchases}

Our third motivation for firms to buy back their shares is capital structure adjustments. Firms with sub-optimal leverage ratios can have an opportunity to increase their debt capacity due to the advantages of using debt. Theoretically, firms may obtain an optimal capital structure by increasing debt to a specific level and by decreasing the number of shares outstanding through share repurchases. The optimal leverage ratio hypothesis argues that share repurchases are intended to increase the debt to assets ratio in order to achieve an optimal capital structure. Repurchasing stocks causes a firm's equity to decrease and the debt ratio to increase, particularly when firms use additional debt to finance the repurchases activities (Dittmar, 2000; Lee et al., 2010). On the other hand, Nohel and Tarhan (1998) argue that share repurchases do not appear as a purely financial transaction addressed to change the firm's capital structure; instead, it is part of a restructuring package which is meant to shrink the assets of the firm. Warr et al. (2012) argue that when equity is overvalued, the overall costs of issuing equity is low and a firm adjusts toward its target leverage by issuing new stocks. Conversely, when equity is undervalued and issuing equity is expensive, firms having below target leverage can move back 
to target leverage by optimizing share repurchases, issuing debt or both. We use Underleverage as a proxy for the firm's deviation from its optimal capital structure. Based on the optimal leverage ratio hypothesis, we conjecture that:

H3. There is a positive association between underleverage and the propensity to buy back shares or intensity of share repurchases.

\subsection{Underpricing and Share Repurchases}

Another well-documented motive for share repurchases is undervaluation. Undervaluation refers to the market price of a stock which is less than its intrinsic value; ${ }^{5}$ therefore, it does not represent the "true" value of the stock. Based on the undervaluation hypothesis, share repurchases decision is intended to signal to the market that stock prices are undervalued (Lee et al., 2010). Julio and Ikenberry (2004) find evidence to support the undervaluation hypothesis as one of the main motives to repurchase shares. Warr et al. (2012) claim that firms with underpriced equity will be more aggressive in repurchasing their shares. A survey-based study confirms that undervaluation is one of the primary reasons for firms to repurchase their shares (Tsetsekos et al., 1996). Similarly, Bonaimé et al. (2016) document that undervaluation is one of the motives to repurchase their shares. They also argue that by repurchasing stock, managers can increase the firm's value by exploiting inside information when the price of their stock in the market is undervalued. They also find, based on a survey of financial executives, such share repurchases are preferred over dividends because of its flexibility in terms of the amount and timing of distributions to investors. IDX firms claim that underpricing of stocks is the primary motive behind their share repurchases policies. They argue that an undervalued stock will be disadvantageous to firms as it does not represent the firm's fundamental value. Hence, if it occurred for a long period, it could cause an unfavourable perception of the firms' prospects.

\footnotetext{
${ }^{5}$ Intrinsic value is defined in details in Table A. 1 in the Appendix.
} 
For the purpose of this study, we test whether this motive, proxied by the variable Underpriced, drives Indonesian firms to increase their share repurchases. Ceteris paribus, in line with the undervaluation hypothesis, underpricing will lead to higher propensity and intensity of share repurchasing. Thus, we posit that:

H4. There is a positive association between underpricing and the propensity to buy back shares or intensity of share repurchases.

\subsection{Regulations and Share Repurchases}

Motivated by the regulatory changes around the world, several studies attempt to investigate the effect of these regulations on the firms' share repurchases. Manconi et al. (2018) support the view that the phenomenon of share repurchases outside the U.S.A. is induced by the enactment of share repurchases regulations. Share repurchases have grown in popularity and importance, not only in market-based-economies such as U.S.A. and U.K. but also in Germany, Japan, Taiwan, and Hong Kong, where it was previously prohibited (Grullon and Ikenberry, 2000). This indicates that the activity of share repurchases in the latter countries was driven by the implementation of regulations allowing firms to repurchase their stocks. Weigand and Baker (2009) argue that an improved regulatory environment drives the intensity of firms to repurchase shares. Similarly, Grullon and Michaely (2002) affirm that the adoption of new rules concerning share repurchases has reduced the concern of managers about the potential risk which is related to illegal market manipulation, as charges were imposed by previous rules. There has not been any study comprehensively examining the impact of regulations on the activity of share repurchases in the Indonesian context. In Indonesia, share repurchases are regulated by the Corporation Limited Act No. 1/1995 as amended by the Limited Corporation Act No 40/2007. The substantial increase of share repurchases activities was driven by the introduction of the Regulation of BAPEPAM-LK No XI.B.3 giving incentives to publicly listed firms to undertake 
repurchases programs without a Shareholders' General Meeting. Therefore, to address the effect of share repurchases regulatory changes, this study provides empirical evidence on the impact of the regulations, proxied by a dummy variable, Regulation, on the intensity of IDX firms' share buybacks. ${ }^{6}$ Our next hypothesis is then as follows:

H5. There is a positive association between regulations and the propensity to buy back shares or intensity of share repurchases.

\subsection{Corporate Governance and Share Repurchases}

Extant literature examines the link between corporate governance mechanisms and the corporate buyback policy. Firms with better governance mechanisms are more likely to be effectively managed, and it is less likely that their managers will extract private benefits. One of the corporate governance tools is the presence of independent directors on board. The existence of independent board members is an important factor to increase investors' trust in the firm because they could be a tool to monitor independently the firm's management. In addition, the presence of independent board members will complement the role of nonindependent board members in providing objective and independent opinions to the management. Therefore, it could be argued that the more effective their function of monitoring managers, the less likely it is that managers will use the firm's resources to their own benefits. Thus, the free cash flow problem will be less likely to materialize which leads to more available cash to be used to buy back shares. Alternatively, a better corporate governance mechanism, represented by larger independent board members could lead to lower cash holdings and thus lower shares repurchases.

\footnotetext{
${ }^{6}$ First, we proxy for regulation as a dummy variable and include it in our main model (Model 1). Further, in section 8 , we use the change in regulation as an exogenous shock to study the determinants of share repurchases in Indonesia.
} 
The type and level of ownership also play a role in determining the firm's corporate governance quality. Leary and Michaely (2011) argue that if firms are held mainly by individual investors, firms tend to pay smaller dividends, and more cash is distributed via share repurchases. The level of concentration is determined by the number of shareholders and the proportion of stocks owned. Firms with a higher degree of concentration are more likely to have a conflict of interest between majority and minority shareholders (Faccio et al., 2001). If the controlling shareholders intend to increase their domination over the firm, the proportion of stocks possessed by an individual or public investor can be reduced via share repurchases programs. In other words, by increasing the number of shares repurchased, controlling shareholders can mitigate principal-principal conflict by alleviating the power of individual shareholders.

Another strong motivation for share repurchases programs in Indonesian firms is that share repurchases are intended to increase the right of control of majority shareholders. For instance, shares buybacks by state-owned publicly listed firms were intended to increase government control over the firms as the government lost its control due to privatization programme in 1998 to execute the International Monetary Fund's recovery programme. ${ }^{7}$ In this study, we test the effect of independent board members, the level of ownership concentration, and the degree of institutional ownership on Indonesian firms' decisions to purchase their shares.

\footnotetext{
${ }^{7}$ The Indonesian parliament urged the government to regain their stock ownership from foreign or private shareholders via share buybacks as in 1998 Indonesia carried out the privatization policy to implement the memorandum between the IMF and Indonesia. In 2007, the Indonesian government repurchased $20 \%$ of the publicly traded SOEs in IDX with a total value of IDR4 trillion $(\$ 250 \mathrm{~m})$. Such buybacks increased investors' confidence as the government was able to take measures to protect capital markets after the global financial crisis in 2008 .
} 


\section{Share Repurchases Regulations in Indonesia}

In Indonesia, share repurchases are conducted by using either a tender offer or open capital market transaction. ${ }^{8}$ In addition, firms are obliged to submit information to the Capital Market Supervisory Board. In a tender offer, a firm announces the share repurchases in a national newspaper, stating a given price and the period of the offering. If no shareholders are interested in selling their stocks, the period will be extended. However, if no public shareholders sell the stock after two periods of offering, then the firm repurchases its stock as a common capital market transaction. Sometimes, shareholders do not sell their stocks because they prefer holding the shares to accept the tender offer. ${ }^{9}$

Regulations concerning stock repurchases can be found in the Limited Corporation Act No 1/1995, articles 30, 31, 32, and 33. However, this Act was amended by the Limited Corporation Act No 40/2007 and stock repurchases were regulated in articles 37, 38, 39, and 40. The main differences between those acts are that the former (No 1/1995) explicitly obliges firms to use net earnings to finance stock repurchases, while the latter (No 40/2007) does not mention the source of funds to finance stock repurchases programs. According to both acts, firms are allowed to repurchase stocks by fulfilling the following conditions: (i) the plan of the share repurchases program must be decided through a general shareholder's meeting; (ii) share repurchases will not cause the value of net worth (total assets minus total debt based on the financial reports legalized by general shareholders' meeting within the last 6 months) to be less than paid-in capital plus a compulsory reserve; (iii) the total value of the stocks which can be repurchased does not exceed $10 \%$ of paid-in capital; (iv) the stock repurchases can be

\footnotetext{
${ }^{8}$ This is different from the methods of share repurchases available in the US: (i) fixed-priced tender offer, (ii) the Dutch auction tender offer, and (iii) the open market repurchases programme (for more detailed discussion see e.g., Cheng and Hou (2013).

${ }^{9}$ An extreme example of share repurchases in IDX was when PT Aqua Golden Mississippi, a firm under the control of Danone, France, tendered its shares in the open market when the firms were voluntarily delisting from IDX. After three rounds of announcements without any response from public shareholders, the firm finally held an extraordinary shareholders' meeting to "force" public shareholders to sell their stocks by paying more than ten times the market price.
} 
authorized by firms for three years. Within this period, a firm must decide to resell the stocks via the right issues or withdraw it as a way of capital reduction.

Other important rules concerning stock repurchases include Legislations number KEP401/BL/2008 and 02/POJK.04/2013. According to these two legislations, firms are allowed to repurchase shares without carrying out a general shareholders' meeting. The legislation will cease to function in case of an unfavorable capital market shock and significant fluctuation. According to the regulation, a significant fluctuation is defined by a $15 \%$ cumulative drop in the market index for more than three consecutive working days.

\section{Sample Selection}

Our sample comprises all non-financial firms listed in Indonesia Stock Exchange (IDX), for the period between 1999 and $2014 .{ }^{10}$ During this period, the Indonesian regulatory authority implemented the 2007's stock repurchases regulation, which we intend to use as an exogenous shock to our models, developed in the following section, to obtain a better understanding of the share repurchases policy of IDX firms.

As of December 2014, there were 502 firms listed in the IDX, but after removing financial firms (74 firms), missing and incomplete data, and eliminating firms carrying out IPO between 2012 and 2014, the final sample is a panel data set that contains 5,386 firm-year observations representing 385 unique firms. In addition to using Reuters Datastream to retrieve firms' financial information, some other non-financial data such as corporate governance data were hand collected from the Indonesia Capital Market Directory (ICMD) ${ }^{11}$ and firms' annual

\footnotetext{
${ }^{10}$ Our data sample starts from 1999 to reflect the regulatory changes that were first implemented in 1998 and because of the absence of buyback activities prior to this year. Our sample ends in 2014 as we intend to have a balanced event window of 8 years before and after the regulatory change in 2007. For example, 8 years before the implementation of the regulation (from 1999 to 2006) and 8 years after the regulatory change (from 2007 to 2014). ${ }^{11}$ The Indonesia Capital Market Directory is an independent data provider in Indonesia.
} 
reports. We have ensured that the data is free from survivorship bias as the observed firms are not being delisted from the stock exchange.

Table 1 shows the number of firms repurchasing stocks and the value of the repurchased stocks over the sample period. The table provides repurchases data in the period before and after the regulatory changes of 2007. Based on our sample, there is no firm that has undertaken share repurchases twice or more in the same year. The number of firms that undertook share repurchases before 2007 is 3.2 firms on average and less than seven firms in each year. On the other hand, the average number of firms that bought back their shares after the regulatory changes reached 18.4 firms. For the first and second year following the regulatory changes, the number of firms with share repurchases reached 27 and 22 firms, respectively. The value of share repurchases after the regulations also increased significantly. The total share repurchases before regulations were 4.8 trillion rupiahs, increasing to 21.6 trillion rupiahs after the implementation of the regulations. Finally, we assess that the sharp drop in the value of share repurchases following the peak in 2008 was caused by the deterioration of economic and market conditions due to the global financial crisis. The financial crisis has negatively affected several sectors in Indonesia such as the weakening of the exchange rate, soaring inflation rate, and the reduction in economic growth. These conditions made firms reluctant to repurchase shares during the period from 2009 to $2011 .^{12}$

\section{[PLEASE INSERT TABLE 1 HERE]}

Table 2 reports the values of the ratios of share repurchases to assets, share repurchases to the market value of equity, and share repurchases to sales. In a study exploring the financial performance of public corporations in eight Asia-Pacific countries (i.e., China, Hong Kong, Indonesia, Japan, Malaysia, South Korea, Singapore and Taiwan), Karolyi and Kim (2017)

\footnotetext{
${ }^{12}$ According to the IDX composite index, the overall yearly return of the IDX market experienced a drop of 50\% during the year 2008. Data can be extracted from: https://finance.yahoo.com/quote/\%5EJKSE?ltr=1.
} 
document that the ratios of share repurchases to assets for the years 2004 and 2014 were $0.20 \%$ and $0.10 \%$, respectively. Table 2 indicates that the corresponding ratios of Indonesian listed firms for the same period were $0.013 \%$ in 2004 and $0.28 \%$ in 2014 . Compared to the average repurchases to assets in the countries above, it was far lower Indonesia in 2004. Yet, in 2014 the same ratio pertaining to the IDX firms exceeded that of their peers in the region.

\section{[PLEASE INSERT TABLE 2 HERE]}

\section{Research Design}

In order to examine the propensity of firms to repurchase their shares, this study employs probit and marginal effects models with a dummy variable, $D U M \_R E P$, which takes the value of 1 for firms that undertake share repurchases, and 0 otherwise.

$\operatorname{Prob}\left(\right.$ DUM $\left._{R E P_{i, t}}=1\right)=\alpha+\beta_{1}$ Dividends $_{i, t-1}+\beta_{2}$ Overpayment $_{i, t-1}+$ $\beta_{3}$ Underpriced $_{i, t-1}+\beta_{4}$ OverCash $_{i, t-1}+\beta_{5}$ UnderLeverage $_{i, t-1}+$ $\beta_{6}$ IndependentBoard $_{i, t-1}+\beta_{7}$ DegreeConcentration $_{i, t-1}+\beta_{8}$ Regulation $_{t}+$ $\beta_{r} \sum_{r=1}^{7}$ Controls $(r)_{i, t-1}+\pi_{p} \sum_{p=1}^{15}$ Year $_{p}+\tau_{q} \sum_{q=1}^{7}$ Industry $_{q}+\varepsilon_{i, t}$

While the above probit model detects the presence of share repurchases, the OLS model is used to analyze the level of share repurchases paid. The dependent variable, Repurchases, is the ratio of share repurchases to total assets.

Repurchases $_{i, t}=\alpha+\beta_{1}$ Dividends $_{i, t-1}+\beta_{2}$ Overpayment $_{i, t-1}+$ $\beta_{3}$ Underpriced $_{i, t-1}+\beta_{4}$ OverCash $_{i, t-1}+\beta_{5}$ UnderLeverage $_{i, t-1}+$ $\beta_{6}$ IndependentBoard $_{i, t-1}+\beta_{7}$ DegreeConcentration $_{i, t-1}+\beta_{8}$ Regulation $_{t}+$ $\beta_{r} \sum_{r=1}^{7}$ Controls $(r)_{i, t-1}+\pi_{p} \sum_{p=1}^{15}$ Year $_{p}+\tau_{q} \sum_{q=1}^{7}$ Industry $_{q}+\varepsilon_{i, t}$

For both models, the vector, Controls, include a set of control variables that are found to affect the firms' decisions to repurchase shares (see e.g., Chen and Wang, 2012; Andriosopoulos and Hoque, 2013; Andriosopoulos et al., 2013). These controls include Size, Growth, MVBV, CAPEX, Tangibility, Profitability, and Risk. Industry and Year represent industry and year dummy variables to control for the effect of industry and time fixed-effects We follow the main 
industry classification adopted by IDX which classifies firms into industry groups based on their 2-digit industry classification. We have a total of eight industry groups: i) Agriculture, ii) Mining, iii) Basic Industry and Chemicals, iv) Miscellaneous Industry, v) Consumers Goods, vi) Property, Real Estate and Building Constructions, vii) Infrastructure, Utilities and Transportations, viii) Others. $\varepsilon$ is the idiosyncratic error term. ${ }^{13}$

In addition to the control variables, both models (1) and (2) contain variables reflecting sub-optimal corporate financial decisions. These variables are: Overpayment, OverCash, and UnderLeverage, which are defined as follows:

First, in line with Andriosopoulos et al. (2018), we define Overpayment using the following model:

Dividends $_{i, t}=\alpha+\beta_{1}$ CashFlow $_{i, t-1}+\beta_{2}$ RetainedEarnings $_{i, t-1}+\beta_{3}$ Cash $_{i, t-1}+$ $\beta_{4} M V B V_{i, t-1}+\beta_{5}$ Size $_{i, t-1}+\beta_{6}$ Leverage $_{i, t-1}+\beta_{7}$ Risk $_{i, t-1}+\beta_{8}$ Age $_{i, t-1}+$

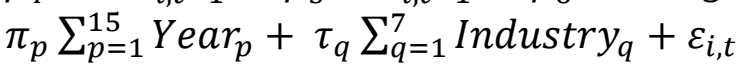

In this setting, the residual $\varepsilon_{\mathrm{i}}$ is used as a proxy for firm $i$ 's excess dividend payment in a given year. A positive (negative) residual indicates that the firm pays more (less) dividends than is required during that year. For the purpose of our study, we define OverPayment as a dummy variable which equals 1 if the residual is positive and 0 otherwise.

Second, in line with previous studies (e.g., Opler et al., 1999; El Kalak and Tosun, 2019; El Kalak et al., 2020), for each year, we estimate the excess cash for firm $i$ as the residual of the following cross-sectional regression model:

Cash $_{i}=\alpha+\beta_{1}$ CashFlow $_{i}+\beta_{2}$ Leverage $_{i}+\beta_{3}$ MVBV $_{i}+\beta_{4}$ Size $_{i}+\beta_{5} N W C_{i}+$ $\beta_{6}$ CAPEX $_{i}+\beta_{7}$ Dividends $_{i}+\beta_{8} R \& D_{i}+\beta_{9}$ Age $_{i}+\varepsilon_{i}$

In this setting, the residual $\varepsilon_{\mathrm{i}}$ is used as a proxy for firm $i$ 's excess cash in a given year. A positive (negative) residual indicates that the firm hoards more (less) cash than it needs for its

\footnotetext{
${ }^{13}$ Detailed definitions of all the variables used in this study are provided in Table A.1 in the Appendix.
} 
normal operational activities and investments during that year. For the purpose of our study, we define OverCash as a dummy variable which is 1 when the residual is positive, which indicates that cash is in excess of normal operations and investments, and 0 otherwise.

Third, following Rajan and Zingales (1995) and Frank and Goyal (2009), we define UnderLeverage using the following model:

Leverage $_{i, t}=\alpha+\beta_{1}$ Profitability $_{i, t}+\beta_{2}$ Size $_{i, t}+\beta_{3} M V B V_{i, t}+$ $\beta_{4}$ IndustryLeverage $_{i, t}+\beta_{5}$ Tangibility $_{i, t}+\beta_{6}$ Depreciation $_{i, t}+\beta_{7}$ Risk $_{i, t}+$ $\beta_{8}$ StockMarket $_{t}+\beta_{9}$ DebtMarket $_{t}+\beta_{10}$ Macroeconomy $_{t}+\pi_{p} \sum_{p=1}^{15}$ Year $_{p}+$ $\tau_{q} \sum_{q=1}^{7}$ Industry ${ }_{q}+\varepsilon_{i, t}$

The residual $\varepsilon_{\mathrm{i}}$ is used as a proxy for firm $i$ 's excess leverage in a given year. A positive (negative) residual indicates that the firm has a higher (lower) level of leverage than optimal during that year. In this setting, we define UnderLeverage as a dummy variable which is 1 when the residual is negative and, 0 otherwise.

\section{Empirical Results}

\subsection{Descriptive statistics}

Table 3 reports the summary statistics. The average value of share repurchases (Repurchases) is only $0.01 \%$ of assets, with a maximum of $1.28 \%$ of assets, and a standard deviation of $0.14 \%$. This indicates that the value of share repurchases is very low compared to the value of their assets. By referring to the value of the Indonesian currency (IDR), the maximum Dividend Per Share is IDR12,000 and IDR69.170, on average. Based on the exchange rate at December 2014 quoted at IDR12,000 per USD, the maximum dividend per share of the IDX firms is only one dollar during the period between 1999 and 2014. This indicates that IDX firms pay low dividends on their shares. Overpayment shows an average of $29.6 \%$ for cash dividends, indicating that less than one-third of firms overpaid.

An interesting figure in table 3 is the value of the Underpriced variable, showing that more than half of the firms are underpriced with an average of $66 \%$. Theoretically, this means 
that the market price of stocks is traded at below their ideal price, at which the market value of stocks should be equal to their intrinsic value. Furthermore, the variable UnderLeverage shows an average of $46 \%$ indicating that nearly half of the firms are underleveraged firms. In addition, more than half of the board members are independent (Independent_Board). This may suggest that the IDX firms are concerned with the implementation of corporate governance practices by employing independent board members in order to promote the effectiveness of good corporate governance practices. The value of Institutional_Ownership is low, at $0.46 \%$ on average. Regarding the value of assets, the firm size indicates a substantial book value of assets due to the high denomination of IDR currency with a low exchange rate. The average firm size (Size) is nearly IDR4 billion, with a minimum of IDR554 million and maximum of IDR233 trillion.

\section{[PLEASE INSERT TABLE 3 HERE]}

Table 4 reports the correlation matrix of the variables used in this study. Higher correlations occur expectedly in the two dependent variables: DUM_REP and Repurchases. To avoid multicollinearity, the regression models do not have any variance inflation factor (VIF) greater than 10 .

\section{[PLEASE INSERT TABLE 4 HERE]}

\subsection{Univariate Analysis}

Table 5 reports the mean (t-test) and median (Wilcoxon) tests for the main explanatory variables based on two groups: repurchasing and non-repurchasing firms. The table reveals that there are significant differences in mean and median values between both groups. For the t-test there are nine variables that have significant differences. With regards to the Wilcoxon test, there are seven variables that show significant differences as represented by their p-values (less than the $1 \%$ level). This indicates that the characteristics of the two groups are fundamentally different from each other. 


\section{[PLEASE INSERT TABLE 5 HERE]}

\subsection{Modeling the tendency to buyback stocks}

Table 6 provides the probit estimations in order to examine the propensity of firms to repurchase shares. Panel A reports the raw coefficients estimation while Panel B reports the marginal effects estimations. Model (1) shows that the propensity of repurchasing stocks is negatively associated with the intensity of dividend payments (Dividend), but it is insignificant. A significant finding would confirm the substitution hypothesis between share repurchases and dividends; i.e., the probability of firms repurchasing shares decreases if the firms pay cash dividends. However, this result supports the findings by Dittmar (2000) and Jiang et al. (2013), documenting that there is weak evidence that share repurchases are a perfect substitution for dividends in the Indonesian market. This is also in line with the recent regulatory changes in 2007, where firms must use net earnings to finance share repurchases rather than using dividend payments. In addition, Cash and Leverage are strongly associated with share repurchases. Firms with higher cash are positively correlated with the likelihood of repurchasing stocks. In contrast, firms with higher leverage are less likely to repurchase stocks.

As per model (2), the variable Overpayment is strongly associated with the propensity to repurchase stocks with a positive sign; thus, supporting our first hypothesis, $H 1$. The positive correlation between Overpayment and Repurchases can be interpreted as an indication that firms with dividend overpayment have a higher propensity to buy back shares. Therefore, this study rejects the complementarity hypothesis by confirming that the probability of firms repurchasing shares does not decrease if they are overpaying dividends.

With respect to the association between excess cash and share repurchases, model (2) includes the main variable of interest, namely Overcash. The result fails to support our second hypothesis, $H 2$, due to the insignificant coefficient. 
The positive and significant coefficient values on Underleverage variable is in line with the optimal leverage ratio hypothesis (Dittmar, 2000; Warr et al., 2012); thus, supporting our third hypothesis, H3. Firms with suboptimal leverage ratios tend to pay more for share repurchases in order to reach the desired level of leverage. This indicates that these firms are more likely to increase debt capacity in order to optimize the capital structure to a specific level. Firms with this strategy can enjoy the benefits of tax advantages. This finding supports the notion that the probability of firms repurchasing shares increases if they are underleveraged.

As shown in Model (3), the coefficient of Underpriced does not have a significant correlation with the propensity to buy back shares. This suggests that the tendency to repurchase shares is not motivated solely by the underpricing of stocks in the market. Therefore, we fail to provide support for our fourth hypothesis, $H 4$. Although some firms in IDX claim that stock repurchases are driven by the undervaluation of stock, this cannot be a generalization.

Finally, the coefficients on the dummy variable Regulation is positive and significant in Models 1 and 2. This highlights the importance of regulations in determining the firms' repurchasing activities. These results provide support for our fifth hypothesis, H5. In addition, the finding is in line with the work of Weigand and Baker (2009) which argues that an improved regulatory environment can give an incentive for firms to undertake more share repurchases programs. For IDX firms, the regulations have increased the incentives to conduct stock repurchases in an effort to overcome problems related to unfavorable stock market conditions.

Panel B reports the marginal effects of explanatory variables on the propensity to repurchase shares. In Model (4), Dividend and Repurchases have a negative but insignificant correlation. However, the variables Cash and Leverage have strong correlations with the firm's propensity to repurchase shares. The coefficient of Cash shows a value of 0.0291 , meaning that one standard deviation (i.e., 0.22) increase in Cash increases the probability of repurchasing shares by 2.9 percentage points. Panel B also reports positive and significant coefficients of 
Overpayment, Overcash, and UnderLeverage, as shown in Model (5). Yet, Underpriced is statistically insignificant; suggesting that underpricing does not have enough power to determine the marginal effect on a firm's repurchasing policy.

\section{[PLEASE INSERT TABLE 6 HERE]}

\subsection{Modeling the intensity of stock repurchases}

Table 7 provides the OLS estimation results with Repurchases as a dependent variable. Examining the coefficients, Dividend has a negative correlation with Repurchases, but the relationship is insignificant. The 2007 regulatory changes obliged IDX firms to set aside net earnings to fulfill the minimum fund reserves or to set cash dividends at a given maximum percentage of net earnings. This requirement limited the funds available to repurchase shares. An obvious substitution relationship between share repurchases and dividends would be consistent with the findings of Grullon and Michaely (2002) and Jiang et al. (2013).

Overpayment has strong correlation with Repurchases, which supports our hypothesis, H1. Overpaying firms tend to pay more for share repurchases. Overcash does not have a significant correlation with share repurchases. These results do not support $H 2$. On the other hand, UnderLeverage is closely correlated with Repurchases. As proposed by the optimal leverage hypothesis, firms having suboptimal leverage use the repurchase program to undertake capital structure adjustment in order to achieve an optimal ratio of leverage.

Previous studies find that being underpriced is one of the firms' motivations to repurchase their stocks (Tsetsekos et al., 1996; Julio and Ikenberry, 2004; Bonaimé et al., 2016). However, this study does not support this hypothesis (H4), as shown by the insignificant coefficient between misvaluation and share repurchases, which may reveal some unique features of the corporate sector in Indonesia. This finding suggests that underpricing is not the only motivation to undertake share repurchases, as revealed by some Indonesian business 
media. Firms may have other motivations to repurchase shares. For example, it may be an attempt of large shareholders to increase their stock ownership, while public shareholders, having low percentages of shares, would like to sell their stocks. As a result, the percentages of those particular shareholders increase relative to total share ownership because of the retirement of stocks previously held by minority shareholders. Another possible explanation is that IDX firms do not have efficiently functioning corporate governance mechanisms. According to Manconi et al. (2018), the undervaluation hypothesis only explains share repurchases if the firm has a certain quality of governance. Finally, the regulations in the corporate sector are important in determining firms' repurchases activities. As shown in Model (2), Regulation has a significant and positive correlation with Repurchases. This finding further supports our fifth hypothesis, $H 5$.

The Independent_Board variable shows a negative and insignificant correlation with Repurchases. As a variable measuring the effectiveness of the corporate governance mechanism, a negative and significant correlation between board independence and share repurchases would indicate that a larger number of independent board members reduces the level of repurchases intensity. One would also expect that better governance yields lower agency conflicts and a lesser free cash flow problem. However, by assuming that a larger ratio of independent board members yields more effective monitoring and less likelihood of managers extracting private benefit from the firm (Coles et al., 2008), this study fails to support the hypothesis that firms with a larger independent board member, as a proxy for better corporate governance quality, pay more to repurchase shares. A possible explanation is that corporate governance mechanisms have not been effectively applied by the IDX firms.

Institutional_Ownership has a positive and significant correlation with Repurchases in all models. As this factor can be a proxy to measure the effectiveness of corporate governance, the existence of institutional investors will have a significant effect on a firm's ownership 
structure. Institutional investors may have a positive influence on the corporate governance mechanism due to their role and incentive to control management. They may help in improving corporate governance quality by mitigating agency costs owing to their central position in the ownership structure. This study finds evidence that the higher the proportion of stocks held by institutional investors, the larger the stock repurchases. Another explanation is that institutional investors, as main shareholders, have strategic long-term plans to increase the percentage of ownership of the firms by increasing the intensity of the repurchases programs. Other minority shareholders who are interested in receiving the repurchases offering will sell their stocks and the proportion of stocks held by institutional investors increases. On the other hand, share repurchases may be an opportunity for institutional shareholders to sell their ownership of the firm and buy other firms' stocks.

[PLEASE INSERT TABLE 7 HERE]

\section{Robustness Tests}

\subsection{Fixed-Effects and the IV-GMM Estimation Methods}

The OLS method has been widely criticized as it strictly assumes that all of the explanatory variables are exogenous. Furthermore, this method generates biased coefficients because the time-specific effects are unobservable, and they correlates with other regressors (Antoniou et al., 2008). To overcome the problem, we use fixed effects estimation and IV-GMM to test the robustness of our estimations by treating the main explanatory variables as endogenous. ${ }^{14}$ In a model with endogenous variables, Arellano and Bond (1991) suggest the use of the instrumental variables (IV) technique by generating lagged values of variables. We use internal

\footnotetext{
${ }^{14}$ In Stata, for static IV_GMM, multiple treatment for a set of potential endogenous explanatory variables is not possible and that in our untabulated results where we use fitted values of the explanatory variables, the quality of the results does not change. Note that it would be very long to report the fitted value calculations of all explanatory variables.
} 
instruments for the factors related to dividends, sub-optimal corporate decisions and corporate governance by using their lags up to three periods.

The IV-GMM requires that the correlation between an instrumental variable $(\mathrm{Z})$ and error $(\eta)$ to be orthogonal, or $\operatorname{Cov}(Z, \eta)=0$, and the covariance between an instrumental and endogenous explanatory variable $(S)$ is different from zero, or $\operatorname{Cov}(S, Z) \neq 0$. Therefore, there will be two tests regarding the endogeneity problem. First, the Hausman test is used to identify whether a potentially exogenous variable is actually endogenous. For Models (4) to (6), the Hausman tests reported are significant at the $1 \%$ level; thus, indicating that Dividends is endogenously determined. Second, the Sargan test is used to test the null hypothesis stating that the overidentifying restrictions are valid (Ho: over identifying restrictions are valid); hence, the p-value should not reject the null hypothesis. For Models (4) to (6), the p-values of Sargan tests are larger than the level of significance at the $10 \%$ level. This suggests that we do not have enough evidence to reject he null hypothesis. Thus, the instrument variables are valid or the model specification is correct. Table 8 then shows that our main results hold after controlling for firm fixed effects and IV-GMM estimation method overcoming the endogeneity and heterogeneity problems.

\section{[PLEASE INSERT TABLE 8 HERE]}

\subsection{Sample Selection Bias}

Heckman's two-step estimation technique is commonly used to investigate a firm's decision on payout policies. It is intended to examine potential sample selection bias. It consists of two steps. The first step deals with the propensity to repurchase shares that examines the likelihood of firms repurchasing shares, and the second one analyzes the intensity of share repurchases which is measured by the amount of share repurchases paid. The OLS model estimation below is a censored regression model which can be used for Heckman's two-step estimation procedures. 
$\left.E_{\left(\text {Repurchase }_{i, t}\right.} / Z_{i, t}=1\right)=\alpha+\beta_{1}$ Dividend $_{i, t-1}+\beta_{2}$ Overpayment $_{i, t-1}+$ $\beta_{3}$ Underpriced $_{i, t-1}+\beta_{4}$ OverCash $_{i, t-1}+\beta_{5}$ UnderLeverage $_{i, t-1}+$

$\beta_{6}$ IndependentBoard $_{i, t-1}+\beta_{7}$ DegreeConcentration $_{i, t-1}+\beta_{8}$ Regulation $_{t}+\beta_{9} \lambda+$

$\beta_{r} \sum_{r=1}^{7}$ Controls $(r)_{i, t-1}+\pi_{p} \sum_{p=1}^{15}$ Year $_{p}+\tau_{q} \sum_{q=1}^{7}$ Industry $_{q}+\varepsilon_{i, t}$

where "E(Repurchases $\left.{ }_{i, t} \mid \mathrm{Z}_{\mathrm{i}, \mathrm{t}}=1\right)$ " indicates the expected intensity level if firms pay to repurchase their shares; $\chi$ is the inverse Mill's ratio obtained for the purpose of selection correction in which a significant Mill's ratio implies the presence of the sample selection bias.

Table 9 provides the results. First of all, the coefficients of the invers Mill's ratio, reported in all models, indicate insignificant values. These insignificant values imply the nonexistence of a sample selection bias. In real-life scenarios, however, there are large differences between firms that repurchase their shares and those who do not. However, due to the very small number of firms that repurchased their shares in our sample, we have high inverse Mill's p-values leading to insignificant results, which can be named as the biased case of 'underrejecting the null hypothesis'.

Overall, the results reported in all of the models of Table 9 (models 1 to 3) are consistent with those provided from our main model in Table 6. Thus, our findings remain qualitatively the same for this model specification.

\section{[PLEASE INSERT TABLE 9 HERE]}

\section{The Effect of Regulatory Changes in $\mathbf{2 0 0 7}$ on Corporate Share Repurchases Policies}

In order to address the effect of share repurchases regulatory changes, this study provides empirical evidence on the impact of the regulations on the intensity of IDX firms' shares repurchasing decisions. ${ }^{15}$ As a consequence of the implementation of the regulations in 2007, IDX firms are able to repurchase their shares easily without obtaining the approval from the

\footnotetext{
${ }^{15}$ As it is beyond the scope of this study, we do not consider the institutional quality and mechanisms to enforce the regulations on firms. For further details on this literature, see Djankov et al. (2003) and Fauver et al. (2017).
} 
Shareholders' General Meeting. In fact, Table 1 shows a sudden jump for the number of firms repurchasing their shares and the ratio of share repurchases to total assets right after 2007. Hence, this natural experiment provides an opportunity to investigate the main determinants of share repurchases in Indonesian firms through an exogenous shock on the intensity of firms to buy back shares.

To do so, we employ the difference-in-differences (DiD) method. The DiD analysis is intended to address problems of endogeneity in the relationship between share repurchases and some endogenously determined explanatory variables. Statistically, this test examines whether there are differential effects for the periods of pre- and post-regulations. By setting 2007 as the demarcation point, this study distinguishes the first sub period from 1999 to 2007, and the subsequent period from 2008 to 2014. The statistical equation model is the following:

$$
\begin{aligned}
\text { Repurchases }_{i, t} & \\
& =\alpha+\beta_{1} \text { Dividend }_{i, t-1}+\beta_{2} \text { Dividends }_{i, t-1} x \text { PostReg } \\
& +\beta_{3} \text { Overpayment }_{i, t-1}+\beta_{4} \text { Overpayment }_{i, t-1} x \text { PostReg } \\
& +\beta_{5} \text { Underpriced }_{i, t-1}+\beta_{6} \text { Underpriced }_{i, t-1} x \text { PostReg } \\
& +\beta_{7} \text { OverCash }_{i, t-1}+\beta_{8} \text { OverCash }_{i, t-1} x \text { PostReg } \\
& +\beta_{9} \text { UnderLeverage }_{i, t-1}+\beta_{10} \text { UnderLeverag }_{i, t-1} x \text { PostReg } \\
& +\beta_{11} \text { IndependentBoard }_{i, t-1} \\
& +\beta_{12} \text { IndependentBoard }_{i, t-1} x \text { PostReg } \\
& +\beta_{13} \text { DegreeConcentration }_{i, t-1} \\
& +\beta_{14} \text { DegreeConcentration }_{i, t-1} x \text { PostReg }+\beta_{15} \text { Regulation }_{i, t} \\
& +\beta_{r} \sum_{r=1}^{7} \text { Controls }(r)_{i, t-1}+\pi_{p} \sum_{p=1}^{15} \text { Year }_{p}+\tau_{q} \sum_{q=1}^{7} \text { Industr }_{q}+\varepsilon_{i, t}
\end{aligned}
$$

Controls include a set of variables that are found to affect the firms' decisions to repurchase shares. These controls include Size, Growth, MVBV, CAPEX, Tangibility, Profitability, and Risk; Industry and Year represent the effects of industry and time fixed-effects.

Table 10 presents the main variables which are assumed to have an impact on share repurchases along with their interaction terms with PostReg, which is a binary dummy indicator 
that is 1 for years after the regulatory changes in 2007 ; 0 , otherwise (i.e., the variable Regulation).

Model (1) shows that the association between Dividends and Repurchases is significant and negative, indicating that they are substitutes. On the other hand, their association becomes positive when Dividends is interacted with PostReg, suggesting that dividends and share repurchases have become complementary to each other after the impact of the regulatory changes. Namely, the regulations have encouraged IDX firms to undertake share repurchases although these firms continue to pay cash dividends to shareholders. The association between Leverage and Repurchases is negative and significant but the corresponding interacted terms for Leverage and Cash are insignificant. These findings imply that the cash holdings and capital structure decisions have not influenced payout policies after the introduction of the regulations.

In Model (2), the variable UnderLeverage is significant without considering the regulations, but this leverage revealing sub-optimality becomes insignificant after considering the interaction term. This indicates that the regulations have changed the motivation of underleveraged firms regarding their share repurchases programs. A positive and significant correlation between OverCash and payout policy would be interpreted as an indicator that overcash firms tend to undertake larger repurchases to minimize the free cash flow held by the firms. However, for our sample firms, the corresponding insignificant (albeit positive) coefficient does not provide any strong support for this conjecture.

Finally, in Model (3), consistent with our previous results, Underpriced does not have any significant correlation with share repurchases. This finding does not support commonly reported significant results especially for the developed markets in the extant literature. Regarding capital structure, both Leverage and its interaction with PostReg have statistically significant correlations with Repurchases, which suggests that the inverse link between leverage and stocks' repurchasing has intensified after the enacted regulations. 
Overall, we conclude that the implementation of the regulations in the Indonesian market has reached most of its goals with respect to altering the firms' share repurchases decisions. For example, after the introduction of the regulatory changes in 2007: (i) the Indonesian stock market has experienced an increase in the number of financial activities where more firms started to attract shareholders selling their stocks. In the same vein, we find that the relationship between dividends and share repurchases changed from being a substitutional relation (before the regulatory change) to a complementary relation (after the change); (ii) the excess cash and excess payout policies become significant determinants of the firms' share repurchases. This indicates reducing the agency cost of free cash flow, whereby shareholders require a larger distribution of firms' cash rather than it being retained by managers; hence, better aligning the interests of shareholders and managers.

However, based on the findings of this study, we argue that due to the weak roles of corporate governance mechanisms already implemented in Indonesian firms, the 2007 regulatory change was not able to fulfil its entire objectives. For example, on a corporate governance level, we do not find any support that firms with larger independent board member, as a proxy for better corporate governance quality, pay more to repurchase shares. This is also why we do not find support for the undervaluation hypothesis, despite the common perception among IDX firms and the business media in that underpricing is the main motive to repurchase shares. The undervaluation hypothesis only explains share repurchases if the firm has a certain quality of governance.

\section{[PLEASE INSERT TABLE 10 HERE]}

\section{Conclusion}

This study examined the factors affecting share repurchases policies of the IDX firms for the period between 1999 and 2014. During this period, Indonesian firms experienced a regulatory 
change in 2007 concerning share repurchases' activities. This natural experiment provides an opportunity to investigate the main determinants of share repurchases in Indonesian firms through an exogenous shock on the intensity of firms to buy back shares. In addition, we provide empirical evidence on the impact of these regulations on the intensity of the IDX firms' shares repurchases programs.

The implications of this study encompass three different aspects. First, from an academic perspective, this is the first study introducing the effects of various sub-optimal financial decisions, i.e., excess dividend payments, excess cash holdings, and sub-optimal leverage positions on the firms' share repurchases decisions. Second, from a theoretical perspective, this study provides further evidence regarding the agency cost of free cash flows, which is related to the repurchases programs particularly in emerging markets. Third, from a practical aspect, this study is particularly important for regulators. We find that regulatory changes implemented in 1998 and especially in 2007 were significantly important in altering the IDX firms' decisions regarding their payout policies. This suggests that the Indonesian Capital Market Supervisory Board needs to consider appropriately any future regulations that would help IDX firms to optimize their share repurchases policies for a healthy and sound corporate sector. 


\section{References}

Aivazian, V. A., Booth, L., Cleary, S., 2006. Dividend smoothing and debt ratings. Journal of Financial and Quantitative Analysis 41, 439-453.

Allen, F., Michaely, R., 2003. Payout policy. Handbook of the Economics of Finance 1, 337429.

Andriosopoulos, D., Andriosopoulos, K., Hoque, H., 2013. Information disclosure, CEO overconfidence, and share buyback completion rates. Journal of Banking \& Finance 37, 5486-5499.

Andriosopoulos, D., De Cesari, A., Stathopoulos, K., 2018. Excess Corporate Payouts and Financial Distress Risk. Available at SSRN 2728942.

Andriosopoulos, D., Hoque, H., 2013. The determinants of share repurchases in Europe. International Review of Financial Analysis 27, 65-76.

Antoniou, A., Guney, Y., Paudyal, K., 2008. The determinants of capital structure: capital market-oriented versus bank-oriented institutions. Journal of Financial and Quantitative Analysis 43, 59-92.

Arellano, M., Bond, S., 1991. Some tests of specification for panel data: Monte Carlo evidence and an application to employment equations. Review of Economic Studies 58, 277-297.

Baker, H. K., Singleton, J. C., Veit, E. T. 2010. Survey Research in Corporate Finance: Bridging The Gap Between Theory and Practice, Oxford University Press.

Bonaimé, A. A., Hankins, K. W., Jordan, B. D., 2016. The cost of financial flexibility: Evidence from share repurchases. Journal of Corporate Finance 38, 345-362.

Boudry, W. I., Kallberg, J. G., Liu, C. H., 2013. Investment opportunities and share repurchases. Journal of Corporate Finance 23, 23-38.

Byrne, J., O'connor, T., 2017. How do creditors respond to disclosure quality? Evidence from corporate dividend payouts. Journal of International Financial Markets, Institutions and Money 49, 154-172.

Chan, K., Ikenberry, D., Lee, I., 2004. Economic sources of gain in stock repurchases. Journal of Financial and Quantitative Analysis 39, 461-479.

Chan, K., Ikenberry, D. L., Lee, I., Wang, Y., 2010. Share repurchases as a potential tool to mislead investors. Journal of Corporate Finance 16, 137-158.

Chen, S.-S., Wang, Y., 2012. Financial constraints and share repurchases. Journal of Financial Economics 105, 311-331. 
Cheng, S.-Y., Hou, H., 2013. The information content of open-market repurchase announcements in Taiwan. Journal of International Financial Markets, Institutions and Money 27, 59-75.

Coles, J. L., Daniel, N. D., Naveen, L., 2008. Boards: Does one size fit all? Journal of Financial Economics 87, 329-356.

Deangelo, H., Deangelo, L., Skinner, D. J., 2004. Are dividends disappearing? Dividend concentration and the consolidation of earnings. Journal of Financial Economics 72, 425-456.

Dhanani, A., Dhanani, A., 2016. Corporate share repurchases in the UK: Perceptions and practices of corporate managers and investors. Journal of Applied Accounting Research $17,331-355$.

Dittmar, A. K., 2000. Why do firms repurchase stock. The Journal of Business 73, 331-355.

Djankov, S., La Porta, R., Lopez-De-Silanes, F., Shleifer, A., 2003. Courts. The Quarterly Journal of Economics 118, 453-517.

Duygun, M., Guney, Y., Moin, A., 2018. Dividend policy of Indonesian listed firms: The role of families and the state. Economic Modelling 75, 336-354.

El Kalak, I., Goergen, M., Guney, Y., 2020. CEO Overconfidence and the Speed of Adjustment of Cash Holdings. European Corporate Governance Institute-Finance Working Paper.

El Kalak, I., Tosun, O. K. 2019. Female Directors, CEO Overconfidence and Excess Cash. Available at SSRN: 3366827.

Faccio, M., Lang, L. H., Young, L., 2001. Dividends and expropriation. American Economic Review, 54-78.

Fauver, L., Loureiro, G., Taboada, A. G., 2017. The impact of regulation on information quality and performance around seasoned equity offerings: International evidence. Journal of Corporate Finance 44, 73-98.

Firth, M., Leung, T. Y., Rui, O. M., 2010. Double signals or single signal? An investigation of insider trading around share repurchases. Journal of International Financial Markets, Institutions and Money 20, 376-388.

Frank, M. Z., Goyal, V. K., 2009. Capital structure decisions: which factors are reliably important? Financial management 38, 1-37.

Grullon, G., Ikenberry, D. L., 2000. What do we know about stock repurchases? Journal of Applied Corporate Finance 13, 31-51.

Grullon, G., Michaely, R., 2002. Dividends, Share Repurchases and the Substitution Hypothesis. Journal of Finance 57, 1649-1684. 
Grullon, G., Michaely, R., 2004. The information content of share repurchase programs. The Journal of Finance 59, 651-680.

Harford, J., Mansi, S. A., Maxwell, W. F., 2008. Corporate governance and firm cash holdings in the US. Journal of Financial Economics 87, 535-555.

Howe, K. M., He, J., Kao, G. W., 1992. One-Time Cash Flow Announcements and Free CashFlow Theory: Share Repurchases and Special Dividends. The Journal of Finance 47, 1963-1975.

Jensen, M. C., 1986. Agency cost of free cash flow, corporate finance, and takeovers. American Economic Review 76, 323-329.

Jiang, Z., Kim, K. A., Lie, E., Yang, S., 2013. Share repurchases, catering, and dividend substitution. Journal of Corporate Finance 21, 36-50.

Jiraporn, P., Ning, Y., 2006. Dividend Policy, Shareholder Rights, and Corporate Governance (Digest Summary). Journal of Applied Finance 16, 24-36.

Julio, B., Ikenberry, D. L., 2004. Reappearing dividends. Journal of Applied Corporate Finance $16,89-100$.

Karolyi, G. A., Kim, D., 2017. Is the Public Corporation Really in Eclipse? Evidence from the Asia-Pacific. Asia-Pacific Journal of Financial Studies 46, 7-31.

Leary, M. T., Michaely, R., 2011. Determinants of dividend smoothing: Empirical evidence. Review of Financial Studies 24, 3197-3249.

Lee, B. S., Suh, J., 2011. Cash holdings and share repurchases: International evidence. Journal of Corporate Finance 17, 1306-1329.

Lee, C. I., Ejara, D. D., Gleason, K. C., 2010. An empirical analysis of European stock repurchases. Journal of Multinational Financial Management 20, 114-125.

Leuz, C., Wysocki, P. D., 2016. The economics of disclosure and financial reporting regulation: Evidence and suggestions for future research. Journal of Accounting Research 54, 525 622.

Manconi, A., Peyer, U., Vermaelen, T., 2018. Are buybacks good for long-term shareholder value? Evidence from buybacks around the world. Journal of Financial and Quantitative Analysis, 1-74.

Massa, M., Rehman, Z., Vermaelen, T., 2007. Mimicking repurchases. Journal of Financial Economics 84, 624-666.

Miller, M. H., Modigliani, F., 1961. Dividend policy, growth, and the valuation of shares. Journal of Business 34, 411-433. 
Moin, A., Guney, Y., El Kalak, I., 2019. The effects of ownership structure, sub-optimal cash holdings and investment inefficiency on dividend policy: evidence from Indonesia. Review of Quantitative Finance and Accounting, forthcoming.

Mulyani, E., Singh, H., Mishra, S., 2016. Dividends, leverage, and family ownership in the emerging Indonesian market. Journal of International Financial Markets, Institutions and Money 43, 16-29.

Nohel, T., Tarhan, V., 1998. Share repurchases and firm performance: new evidence on the agency costs of free cash flow. . Journal of Financial Economics 49, 187-222.

Opler, T., Pinkowitz, L., Stulz, R., Williamson, R., 1999. The determinants and implications of corporate cash holdings. Journal of Financial Economics 52, 3-46.

Rajan, R. G., Zingales, L., 1995. What do we know about capital structure? Some evidence from international data. The Journal of Finance 50, 1421-1460.

Rau, P. R., Stouraitis, A., 2011. Patterns in the timing of corporate event waves. Journal of Financial and Quantitative Analysis 46, 209-246.

Tsetsekos, G. P., Liu, F.-Y., Floros, N., 1996. An examination of open market stock repurchases: cash flow signalling, investments, and Tobin's Q. Applied Financial Economics 6, 9-18.

Von Eije, H., Megginson, W. L., 2008. Dividends and share repurchases in the European Union. Journal of Financial Economics 89, 347-374.

Warr, R. S., Elliott, W. B., Koëter-Kant, J., Öztekin, Ö., 2012. Equity mispricing and leverage adjustment costs. Journal of Financial and Quantitative Analysis 47, 589-616.

Weigand, R. A., Baker, H. K., 2009. Changing perspectives on distribution policy: The evolution from dividends to share repurchase. Managerial Finance 35, 479-492. 
Table 1

Time series distribution of the number of firms repurchasing stocks and the total repurchases value.

$\begin{array}{llll}\text { Year } & \begin{array}{l}\text { No of firms } \\ \text { listed in IDX }\end{array} & \begin{array}{l}\text { Number of firms } \\ \text { repurchasing stocks }\end{array} & \begin{array}{l}\text { Percentage of firms } \\ \text { repurchasing stocks (\%) }\end{array}\end{array} \begin{aligned} & \text { Total repurchases } \\ & \text { (IDR000) }\end{aligned}$

\begin{tabular}{|c|c|c|c|c|}
\hline \multicolumn{5}{|c|}{ Before and until regulatory changes in 2007} \\
\hline 1999 & 177 & 2 & 1.13 & $12,949,368$ \\
\hline 2000 & 215 & 2 & 0.93 & $13,704,000$ \\
\hline 2001 & 222 & 7 & 3.15 & $641,166,000$ \\
\hline 2002 & 232 & 6 & 2.59 & $1,215,801,665$ \\
\hline 2003 & 235 & 2 & 0.78 & $16,056,000$ \\
\hline 2004 & 255 & 2 & 0.78 & $40,669,000$ \\
\hline 2005 & 264 & 1 & 0.38 & $525,000,000$ \\
\hline 2006 & 281 & 2 & 0.71 & $952,211,000$ \\
\hline 2007 & 312 & 5 & 1.60 & $1,455,981,496$ \\
\hline \multicolumn{5}{|c|}{ After regulatory changes in 2007} \\
\hline 2008 & 342 & 27 & 7.89 & $5,137,572,582$ \\
\hline 2009 & 361 & 22 & 6.09 & $899,251,177$ \\
\hline 2010 & 374 & 9 & 2.41 & $514,978,735$ \\
\hline 2011 & 384 & 8 & 2.08 & $2,860,968,016$ \\
\hline 2012 & 385 & 14 & 3.64 & $2,663,206,483$ \\
\hline 2013 & 385 & 23 & 5.97 & $5,706,984,187$ \\
\hline 2014 & 384 & 26 & 6.77 & $3,851,085,365$ \\
\hline
\end{tabular}


Table 2

Time series distribution of the main ratios related to share repurchases.

\begin{tabular}{|c|c|c|c|}
\hline Year & Repurchases/ Assets & $\begin{array}{l}\text { Repurchases / Market value of } \\
\text { equity }\end{array}$ & Repurchases /Sales \\
\hline \multicolumn{4}{|c|}{ Before and until regulatory changes in 2007} \\
\hline 1999 & 0.00041 & 0.00037 & 0.00053 \\
\hline 2000 & 0.00003 & 0.00004 & 0.00004 \\
\hline 2001 & 0.00102 & 0.00557 & 0.00100 \\
\hline 2002 & 0.00125 & 0.00262 & 0.00105 \\
\hline 2003 & 0.00004 & 0.00011 & 0.00003 \\
\hline 2004 & 0.00013 & 0.00001 & 0.00002 \\
\hline 2005 & 0.00078 & 0.00043 & 0.00105 \\
\hline 2006 & 0.00013 & 0.00005 & 0.00019 \\
\hline 2007 & 0.00131 & 0.00023 & 0.00052 \\
\hline \multicolumn{4}{|c|}{ After regulatory changes in 2007} \\
\hline 2008 & 0.00357 & 0.00593 & 0.00390 \\
\hline 2009 & 0.00143 & 0.00344 & 0.00247 \\
\hline 2010 & 0.00170 & 0.00269 & 0.00160 \\
\hline 2011 & 0.00086 & 0.00100 & 0.00363 \\
\hline 2012 & 0.00119 & 0.00083 & 0.00244 \\
\hline 2013 & 0.00466 & 0.00692 & 0.00812 \\
\hline 2014 & 0.00280 & 0.00381 & 0.00123 \\
\hline
\end{tabular}


Table 3

Summary Statistics

\begin{tabular}{|c|c|c|c|c|c|}
\hline Variable & $\begin{array}{l}\text { Number } \\
\text { observations }\end{array}$ & of Mean & Std. Dev. & Min & $\operatorname{Max}$ \\
\hline DUM_REP & 4,797 & 0.0302 & 0.1712 & 0 & 1 \\
\hline Repurchases & 4,765 & 0.0001 & 0.0014 & 0 & 0.0128 \\
\hline Dividends per share (IDR) & 4,492 & 69.170 & 570.79 & 0 & 12,000 \\
\hline Overpayment & 4,797 & 0.2964 & 0.4567 & 0 & 1 \\
\hline Underpriced & 3,977 & 0.6582 & 0.4743 & 0 & 1 \\
\hline Overcash & 4,797 & 0.4725 & 0.4993 & 0 & 1 \\
\hline UnderLeverage & 4,797 & 0.4575 & 0.4982 & 0 & 1 \\
\hline Cash & 4,759 & 0.1544 & 0.2222 & -0.3061 & 1.1584 \\
\hline Leverage & 4,775 & 0.2882 & 0.2173 & 0 & 0.8633 \\
\hline Independent_Board & 3,394 & 0.5401 & 0.3104 & 0 & 1 \\
\hline Degree_Concentration & 4,780 & 0.3052 & 0.2212 & 0.0170 & 0.9447 \\
\hline Institutional_Ownership & 2,826 & 0.0046 & 0.0280 & 0 & 0.45 \\
\hline Regulation & 4,797 & 0.5442 & 0.4980 & 0 & 1 \\
\hline Size (in millions) & 4,784 & $4,189,404$ & $11,176,689$ & 553,991 & $233,000,000$ \\
\hline Growth & 4,657 & 0.2053 & 0.3061 & -0.4874 & 1.2681 \\
\hline MVBV & 4,564 & 1.3644 & 0.6492 & 0.4266 & 3.6372 \\
\hline CAPEX & 4,780 & 0.0564 & 0.0693 & 0 & 0.3671 \\
\hline Tangibility & 4,782 & 0.3981 & 0.2462 & 0.0022 & 0.9221 \\
\hline Profitability & 4,754 & 0.0813 & 0.1209 & -0.2921 & 0.5332 \\
\hline Risk & 4,731 & 0.8018 & 0.5931 & -0.6120 & 2.2160 \\
\hline \multicolumn{6}{|c|}{$\begin{array}{l}\text { Notes: This table provides a summary statistics of the main variables used in this study. The values are based on } 385 \text { firms listed } \\
\text { in IDX over the period from } 1999 \text { to } 2014 \text {. Differences in the number of firm-year observations are due to missing data. Firms } \\
\text { that were undertaking IPOs after } 2011 \text { are excluded from the sample to obtain a minimum of four years consecutive observations. } \\
\text { Size is in million of Indonesian Rupiah (IDR) by deflating it with the production price index (PPI) of World Bank data. The } \\
\text { dummy variables of the table include DUM_REP, Overpayment, Underpriced, OverCash, UnderLeverage, and Regulation. } \\
\text { Table A.1 in the Appendix provides detailed definitions of all the variables used in this study. }\end{array}$} \\
\hline
\end{tabular}


Table 4

Correlation matrix

\begin{tabular}{|c|c|c|c|c|c|c|c|c|c|c|c|c|c|c|c|c|c|c|c|c|}
\hline & & (1) & (2) & (3) & (4) & (5) & (6) & (7) & (8) & (9) & (10) & (11) & (12) & (13) & (14) & (15) & (16) & (17) & (18) & (19) \\
\hline DUM_REP & (1) & 1 & & & & & & & & & & & & & & & & & & \\
\hline Repurchases & (2) & 0.7953 & 1 & & & & & & & & & & & & & & & & & \\
\hline Dividends & (3) & 0.0667 & 0.0669 & 1 & & & & & & & & & & & & & & & & \\
\hline Overpayment & (4) & 0.1218 & 0.1107 & 0.2769 & 1 & & & & & & & & & & & & & & & \\
\hline Underpriced & (5) & -0.0017 & 0.004 & 0.0735 & 0.073 & 1 & & & & & & & & & & & & & & \\
\hline Overcash & (6) & 0.0519 & 0.0437 & 0.0722 & -0.0034 & -0.0034 & 1 & & & & & & & & & & & & & \\
\hline UnderLeverage & (7) & 0.0794 & 0.0752 & 0.243 & -0.0175 & 0.0659 & -0.0344 & 1 & & & & & & & & & & & & \\
\hline Cash & (8) & 0.0274 & 0.007 & 0.0081 & 0.0078 & -0.0385 & 0.0674 & -0.0186 & 1 & & & & & & & & & & & \\
\hline Leverage & (9) & -0.0154 & 0.0063 & 0.1946 & 0.0379 & 0.0265 & -0.0149 & 0.1043 & -0.0333 & 1 & & & & & & & & & & \\
\hline Independent_Board & (10) & 0.0772 & 0.1028 & -0.0155 & 0.0062 & -0.0307 & -0.0399 & -0.0118 & 0.0402 & -0.0361 & 1 & & & & & & & & & \\
\hline Degree_Concentration & (11) & 0.0879 & 0.0619 & 0.0177 & 0.0012 & -0.0858 & 0.0001 & 0.0628 & 0.1714 & 0.0681 & 0.1037 & 1 & & & & & & & & \\
\hline Institutional_Ownership & (12) & 0.1646 & 0.1233 & 0.2791 & 0.0728 & -0.1013 & 0.0283 & 0.0766 & 0.1428 & 0.0904 & 0.0387 & 0.1492 & 1 & & & & & & & \\
\hline Regulation & (13) & 0.0153 & -0.0137 & 0.0038 & -0.0273 & -0.0554 & 0.0509 & -0.0158 & -0.0252 & -0.0446 & 0.0171 & 0.0026 & 0.152 & 1 & & & & & & \\
\hline Size & (14) & 0.0239 & 0.0465 & 0.2246 & 0.0737 & -0.0278 & 0.044 & 0.0351 & 0.095 & 0.1489 & 0.0224 & 0.0687 & 0.148 & 0.0475 & 1 & & & & & \\
\hline Growth & (15) & 0.0994 & 0.0894 & 0.1114 & -0.0094 & -0.0503 & 0.1008 & 0.0219 & 0.0586 & -0.0072 & 0.0331 & 0.0553 & 0.2037 & 0.1843 & 0.1538 & 1 & & & & \\
\hline MVBV & (16) & 0.0838 & 0.0799 & 0.1347 & 0.0393 & -0.0417 & -0.0204 & 0.041 & -0.0128 & 0.067 & 0.0115 & 0.0641 & 0.1719 & 0.0596 & 0.1487 & 0.5761 & 1 & & & \\
\hline CAPEX & (17) & -0.0556 & -0.0788 & -0.298 & 0.0353 & -0.0888 & -0.0746 & -0.6601 & 0.0318 & -0.132 & 0.0236 & -0.1006 & 0.0873 & -0.0237 & -0.0592 & -0.0165 & 0.0264 & 1 & & \\
\hline Tangibility & (18) & 0.0036 & 0.0034 & -0.0663 & -0.0132 & -0.0828 & -0.1999 & -0.0455 & 0.0228 & 0.0119 & -0.0155 & -0.0117 & 0.179 & -0.0458 & 0.0169 & 0.1332 & 0.3283 & 0.2733 & 1 & \\
\hline Profitability & (19) & 0.0552 & 0.0933 & 0.4703 & 0.0752 & 0.0837 & 0.0855 & 0.1359 & -0.0299 & 0.1651 & -0.0383 & 0.0254 & 0.1179 & 0.0804 & 0.2889 & 0.1154 & 0.1301 & -0.3308 & -0.1479 & 1 \\
\hline Risk & (20) & 0.0449 & 0.0181 & 0.002 & 0.0963 & -0.0141 & 0.0386 & 0.0462 & 0.0269 & -0.061 & 0.0175 & -0.0654 & 0.3466 & 0.0337 & -0.0516 & 0.013 & -0.0177 & 0.0162 & -0.033 & -0.0214 \\
\hline
\end{tabular}


Table 5

Univariate Analyses

\begin{tabular}{|c|c|c|c|c|c|c|c|c|c|c|}
\hline & \multicolumn{3}{|c|}{$\begin{array}{l}\text { Repurchasers } \\
(\mathrm{N}=80)\end{array}$} & \multicolumn{3}{|c|}{$\begin{array}{l}\text { Non-repurchasers } \\
(\mathrm{N}=305)\end{array}$} & \multicolumn{2}{|c|}{ t-test } & \multicolumn{2}{|c|}{ Wilcoxon test } \\
\hline & Mean & Median & SD & Mean & Median & SD & t-test & p-value & Z-test & p-value \\
\hline Dividends & 2.833 & 2.785 & 1.453 & 2.965 & 2.833 & 1.544 & 1.552 & 0.122 & 1.558 & 0.119 \\
\hline Overpayment & 1.000 & 1.000 & 0.000 & 1.000 & 1.000 & 0.000 & - & - & - & - \\
\hline Underpriced & 1.000 & 1.000 & 0.000 & 1.000 & 1.000 & 0.000 & - & - & - & - \\
\hline Overcash & 1.000 & 1.000 & 0.000 & 1.000 & 1.000 & 0.000 & - & - & - & - \\
\hline UnderLeverage & 1.000 & 1.000 & 0.000 & 1.000 & 1.000 & 0.000 & - & - & - & - \\
\hline Cash & 0.267 & 0.255 & 0.386 & 0.299 & 0.266 & 0.373 & -3.524 & 0.000 & -3.203 & 0.001 \\
\hline Leverage & 0.410 & 0.377 & 0.212 & 0.404 & 0.358 & 0.208 & -19.197 & 0.000 & -1.242 & 0.214 \\
\hline Independent_Board & 0.634 & 0.500 & 0.234 & 0.638 & 0.600 & 0.215 & 16.917 & 0.000 & 1.092 & 0.275 \\
\hline Degree_Concentration & 0.421 & 0.365 & 0.231 & 0.412 & 0.339 & 0.234 & 0.267 & 0.791 & 1.369 & 0.171 \\
\hline Institutional_Ownership & 0.496 & 0.600 & 0.280 & 0.517 & 0.600 & 0.276 & -5.518 & 0.000 & -4.715 & 0.000 \\
\hline Regulation & 1.000 & 1.000 & 0.000 & 1.000 & 1.000 & 0.000 & - & - & - & - \\
\hline Size & 16.453 & 19.522 & 7.725 & 18.927 & 21.696 & 7.075 & -6.836 & 0.000 & -9.687 & 0.000 \\
\hline Growth & 0.251 & 0.250 & 0.431 & 0.284 & 0.269 & 0.413 & -3.708 & 0.000 & -3.933 & 0.000 \\
\hline MVBV & 1.420 & 1.275 & 0.672 & 1.485 & 1.366 & 0.647 & -0.697 & 0.486 & -3.944 & 0.000 \\
\hline CAPEX & 0.402 & 0.336 & 0.249 & 0.406 & 0.343 & 0.244 & -1.178 & 0.239 & -0.883 & 0.377 \\
\hline Tangibility & 0.464 & 0.436 & 0.228 & 0.462 & 0.448 & 0.227 & -1.431 & 0.153 & -1.475 & 0.140 \\
\hline Profitability & 0.273 & 0.234 & 0.400 & 0.313 & 0.255 & 0.357 & 23.499 & 0.000 & -1.009 & 0.313 \\
\hline Risk & 0.782 & 0.742 & 0.656 & 1.043 & 1.145 & 0.537 & -7.690 & 0.000 & -7.732 & 0.000 \\
\hline
\end{tabular}

Notes: This table reports the mean (t-test) and median (Wilcoxon test) tests for the main explanatory variables based on two groups: repurchasing ( 80 firms) and non-repurchasing firms ( 305 firms). Repurchasers defined as those firms that have repurchased shares at least once in their life (i.e. within the sample period between 1999 and 2014 ), and Non-Repurchasers defined as those that have never repurchased shares during the sample period (1999-2014). The values are based on 3,745 firms-year observations of Non-repurchasing firms, and 1,050 firm-year observations of Repurchasing firms. Based on the data, there is no firm repurchasing shares more than once in a specific year. For variables constructed by binary dummies, the tests do not give statistical values as they have equal mean, median and standard deviation. Table A.1 in the Appendix provides detailed definitions of all the variables used in this study. 
Table 6

Panel probit models for the propensity to repurchase shares

\begin{tabular}{|c|c|c|c|c|c|c|}
\hline \multirow{2}{*}{ 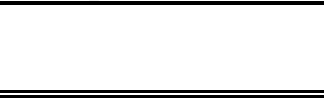 } & \multicolumn{3}{|c|}{ Panel A. Raw Coefficients } & \multicolumn{3}{|c|}{ Panel B. Marginal Effects } \\
\hline & $(1)$ & (2) & (3) & (4) & $(5)$ & $(6)$ \\
\hline & $\begin{array}{l}-0.00289 \\
(0.0494)\end{array}$ & 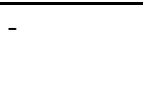 & - & $\begin{array}{l}-0.0001 \\
(0.0013)\end{array}$ & - & - \\
\hline Overpayment & - & $\begin{array}{l}0.928 * * * \\
(0.176)\end{array}$ & - & & $\begin{array}{l}0.0357 * * * \\
(0.0074)\end{array}$ & - \\
\hline Underpriced & - & - & $\begin{array}{l}0.132 \\
(0.162)\end{array}$ & - & - & $\begin{array}{l}0.0020 \\
(0.0046)\end{array}$ \\
\hline OverCash & - & $\begin{array}{l}0.242 \\
(0.161)\end{array}$ & - & - & $\begin{array}{l}0.0119 * * \\
(0.0049)\end{array}$ & - \\
\hline UnderLeverage & - & $\begin{array}{l}0.639 * * * \\
(0.180)\end{array}$ & - & - & $\begin{array}{l}0.0159 * * * \\
(0.0051)\end{array}$ & - \\
\hline Cash & $\begin{array}{l}0.902 * * \\
(0.366)\end{array}$ & - & $\begin{array}{l}0.628 \\
(0.408)\end{array}$ & $\begin{array}{l}0.0291 * * \\
(0.0129)\end{array}$ & - & $\begin{array}{l}0.0183 \\
(0.0135)\end{array}$ \\
\hline Leverage & $\begin{array}{l}-1.916^{* * * *} \\
(0.629)\end{array}$ & - & $\begin{array}{l}-2.504 * * * \\
(0.728)\end{array}$ & $\begin{array}{l}-0.051 * * * \\
(0.0158)\end{array}$ & - & $\begin{array}{l}-0.0571 * * * \\
(0.0149)\end{array}$ \\
\hline Independent_Board & 0.107 & 0.140 & 0.0944 & -0.0029 & -0.0011 & -0.0026 \\
\hline & $(0.297)$ & $(0.298)$ & $(0.330)$ & $(0.0078)$ & $(0.0071)$ & $(0.0078)$ \\
\hline Degree_Concentration & -0.222 & -0.349 & -0.0958 & $-0.0234 * *$ & $-0.0217 * *$ & $-0.0222 *$ \\
\hline & $(0.494)$ & $(0.529)$ & $(0.558)$ & $(0.0117)$ & $(0.0110)$ & $(0.0114)$ \\
\hline Institutional_Ownership & $\begin{array}{l}5.214 * * * \\
(1.945)\end{array}$ & $\begin{array}{l}6.026 * * * \\
(1.987)\end{array}$ & $\begin{array}{l}6.024 * * * \\
(2.078)\end{array}$ & $\begin{array}{l}0.126^{*} \\
(0.0649)\end{array}$ & $\begin{array}{l}0.131 * * \\
(0.0532)\end{array}$ & $\begin{array}{l}0.137 * * \\
(0.0623)\end{array}$ \\
\hline Regulation & $\begin{array}{l}0.875^{*} \\
(0.456)\end{array}$ & $\begin{array}{l}0.865^{* *} \\
(0.425)\end{array}$ & $\begin{array}{l}0.699 \\
(0.497)\end{array}$ & $\begin{array}{l}0.0177 * * * \\
(0.0053)\end{array}$ & $\begin{array}{l}0.0153 * * * \\
(0.0050)\end{array}$ & $\begin{array}{l}0.0167 * * * \\
(0.0052)\end{array}$ \\
\hline Size & $\begin{array}{l}0.436 * * * \\
(0.0832)\end{array}$ & $\begin{array}{l}0.412 * * * \\
(0.0849)\end{array}$ & $\begin{array}{l}0.443 * * * \\
(0.0917)\end{array}$ & $\begin{array}{l}0.0145 \text { *** } \\
(0.0021)\end{array}$ & $\begin{array}{l}0.0115^{* * *} \\
(0.0017)\end{array}$ & $\begin{array}{l}0.0129 * * * \\
(0.0018)\end{array}$ \\
\hline Growth & $\begin{array}{l}-0.226 \\
(0.299)\end{array}$ & $\begin{array}{l}-0.238 \\
(0.291)\end{array}$ & $\begin{array}{l}-0.192 \\
(0.340)\end{array}$ & $\begin{array}{l}-0.0061 \\
(0.0094)\end{array}$ & $\begin{array}{l}-0.0068 \\
(0.0076)\end{array}$ & $\begin{array}{l}-0.0039 \\
(0.0090)\end{array}$ \\
\hline MVBV & $\begin{array}{l}-0.255^{*} \\
(0.144)\end{array}$ & $\begin{array}{l}-0.138 \\
(0.145)\end{array}$ & $\begin{array}{l}-0.265^{*} \\
(0.151)\end{array}$ & $\begin{array}{l}-0.0092 * * \\
(0.0041)\end{array}$ & $\begin{array}{l}-0.0037 \\
(0.0034)\end{array}$ & $\begin{array}{l}-0.0092^{* *} \\
(0.0038)\end{array}$ \\
\hline CAPEX & $\begin{array}{l}2.287 * \\
(1.379)\end{array}$ & $\begin{array}{l}4.168 * * * \\
(1.248)\end{array}$ & $\begin{array}{l}3.538 * * \\
(1.431)\end{array}$ & $\begin{array}{l}0.0781^{*} \\
(0.0442)\end{array}$ & $\begin{array}{l}0.116 * * * \\
(0.0341)\end{array}$ & $\begin{array}{l}0.100 * * \\
(0.0438)\end{array}$ \\
\hline Tangibility & $\begin{array}{l}-0.474 \\
(0.509)\end{array}$ & $\begin{array}{l}-0.558 \\
(0.497)\end{array}$ & $\begin{array}{l}-0.479 \\
(0.553)\end{array}$ & $\begin{array}{l}-0.0208 \\
(0.0129)\end{array}$ & $\begin{array}{l}-0.0170 * \\
(0.0103)\end{array}$ & $\begin{array}{l}-0.0195 \\
(0.0123)\end{array}$ \\
\hline Profitability & $\begin{array}{l}-0.0396 \\
(0.745)\end{array}$ & $\begin{array}{l}1.126 \\
(0.726)\end{array}$ & $\begin{array}{l}-0.209 \\
(0.812)\end{array}$ & $\begin{array}{l}0.0082 \\
(0.0235)\end{array}$ & $\begin{array}{l}0.0287 \\
(0.0188)\end{array}$ & $\begin{array}{l}0.0089 \\
(0.0222)\end{array}$ \\
\hline Risk & $\begin{array}{l}-0.118 \\
(0.140)\end{array}$ & $\begin{array}{l}-0.236 \\
(0.147)\end{array}$ & $\begin{array}{c}-0.0436 \\
(0.158)\end{array}$ & $\begin{array}{l}-0.0047 \\
(0.0037)\end{array}$ & $\begin{array}{l}-0.0057 * \\
(0.0032)\end{array}$ & $\begin{array}{l}-0.0026 \\
(0.0037)\end{array}$ \\
\hline Constant & $\begin{array}{l}-11.61 * * * \\
(1.838)\end{array}$ & $\begin{array}{l}-12.36^{* * * *} \\
(1.871)\end{array}$ & $\begin{array}{l}-11.90^{* * * *} \\
(2.044)\end{array}$ & $\begin{array}{l}- \\
-\end{array}$ & - & - \\
\hline $\begin{array}{l}\text { No. Obs. } \\
\text { No. Firms } \\
\text { Pseudo } \mathrm{R}^{2}\end{array}$ & $\begin{array}{l}2,459 \\
349 \\
0.1619\end{array}$ & $\begin{array}{l}2,477 \\
350 \\
0.2067\end{array}$ & $\begin{array}{l}2,329 \\
348 \\
0.1619\end{array}$ & & & \\
\hline $\begin{array}{l}\text { Notes: The table presents th } \\
\text { dependent variable is a dum } \\
\text { for the period from } 1995 \text { to } 2 \\
\text { of missing data. Panel A rep } \\
\text { variable. All firm-specific v } \\
\text { industry dummies. } * * *, * * \\
\text { consistent standard errors ar }\end{array}$ & $\begin{array}{l}\text { inants of th } \\
\text { the value } \\
\text { total numb } \\
\text { aw coeffic } \\
\text { re winsoriz } \\
\text { cate statist } \\
\text { arentheses. }\end{array}$ & $\begin{array}{l}\text { pensity of } \\
\text { a firm re } \\
\text { observatic } \\
\text { f the prob } \\
1 \% \text { and } 9 \\
\text { gnificance }\end{array}$ & $\begin{array}{l}\text { repurchas } \\
\text { ses its she } \\
797 \text { firm- } \\
\text { hation, an } \\
\text { liminate } \\
0.01,0.0\end{array}$ & $\begin{array}{l}\text { g the pro } \\
\text { d } 0 \text { otherv } \\
\text { however, } \\
\text { I B shows } \\
\text { uence of o } \\
.10 \text { level, }\end{array}$ & $\begin{array}{l}\text { nation and } \\
\text { e panel data } \\
\text { ber varies i } \\
\text { ginal effect } \\
\text { The regress } \\
\text { ively. Robu }\end{array}$ & $\begin{array}{l}\text { nal effects. The } \\
\text { ist of } 385 \text { firms } \\
1 \text { model because } \\
\text { mation for each } \\
\text { nclude time and } \\
\text { eroskedasticity- }\end{array}$ \\
\hline
\end{tabular}


Table 7

Panel OLS method for the intensity to buy back shares

\begin{tabular}{|c|c|c|c|}
\hline & $(1)$ & $(2)$ & (3) \\
\hline "Dividends & $\begin{array}{l}-0.0007 \\
(0.0023)\end{array}$ & 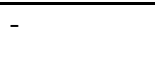 & - \\
\hline Overpayment & - & $\begin{array}{l}0.038 * * * \\
(0.0082)\end{array}$ & - \\
\hline Underpriced & - & - & $\begin{array}{l}0.0044 \\
(0.0072)\end{array}$ \\
\hline OverCash & - & $\begin{array}{l}0.0116 \\
(0.0074)\end{array}$ & - \\
\hline UnderLeverage & - & $\begin{array}{l}0.0224 * * * \\
(0.0064)\end{array}$ & - \\
\hline Cash & $\begin{array}{l}0.0458 \\
(0.0303)\end{array}$ & - & $\begin{array}{l}- \\
(0.0303)\end{array}$ \\
\hline Leverage & $\begin{array}{l}-0.0645 * * * \\
(0.0177)\end{array}$ & - & $\begin{array}{l}-0.0689 * * * \\
(0.0151)\end{array}$ \\
\hline Independent_Board & $\begin{array}{l}-0.0109 \\
(0.0096)\end{array}$ & $\begin{array}{l}-0.0091 \\
(0.0095)\end{array}$ & $\begin{array}{l}-0.0107 \\
(0.0099)\end{array}$ \\
\hline Degree_Concentration & $\begin{array}{l}-0.0231 \\
(0.0142)\end{array}$ & $\begin{array}{l}-0.0255^{*} \\
(0.0146)\end{array}$ & $\begin{array}{l}-0.0228 \\
(0.0147)\end{array}$ \\
\hline Institutional_Ownership & $\begin{array}{l}0.563 * * \\
(0.287)\end{array}$ & $\begin{array}{l}0.578 * * \\
(0.285)\end{array}$ & $\begin{array}{l}0.620 * * \\
(0.304)\end{array}$ \\
\hline Regulation & $\begin{array}{l}-0.631 \\
(0.456)\end{array}$ & $\begin{array}{l}0.0475 * * * \\
(0.0166)\end{array}$ & $\begin{array}{l}0.0067 \\
(0.0160)\end{array}$ \\
\hline Size & $\begin{array}{l}0.0138 * * * \\
(0.0031)\end{array}$ & $\begin{array}{l}0.0118 \text { **** } \\
(0.0026)\end{array}$ & $\begin{array}{l}0.0127 * * * \\
(0.0029)\end{array}$ \\
\hline Growth & $\begin{array}{l}-0.0191 \\
(0.0119)\end{array}$ & $\begin{array}{l}-0.0098 \\
(0.0116)\end{array}$ & $\begin{array}{l}-0.0186 \\
(0.0123)\end{array}$ \\
\hline MVBV & $\begin{array}{l}0.0012 \\
(0.0048)\end{array}$ & $\begin{array}{l}0.0003 \\
(0.0046)\end{array}$ & $\begin{array}{l}0.0004 \\
(0.0047)\end{array}$ \\
\hline CAPEX & $\begin{array}{l}0.0404 \\
(0.0815)\end{array}$ & $\begin{array}{l}0.111^{*} \\
(0.0608)\end{array}$ & $\begin{array}{l}0.0809 \\
(0.0816)\end{array}$ \\
\hline Tangibility & $\begin{array}{l}-0.0138 \\
(0.0171)\end{array}$ & $\begin{array}{l}-0.0126 \\
(0.0164)\end{array}$ & $\begin{array}{l}-0.0102 \\
(0.0152)\end{array}$ \\
\hline Profitability & $\begin{array}{l}0.0479 \\
(0.0294)\end{array}$ & $\begin{array}{l}0.0591 * \\
(0.0323)\end{array}$ & $\begin{array}{l}0.0529 * \\
(0.0302)\end{array}$ \\
\hline Risk & $\begin{array}{l}-0.0084 * \\
(0.0049)\end{array}$ & $\begin{array}{l}-0.0111^{* *} \\
(0.0048)\end{array}$ & $\begin{array}{l}-0.0066 \\
(0.0049)\end{array}$ \\
\hline Constant & $\begin{array}{l}0.397 \\
(0.459)\end{array}$ & $\begin{array}{l}-0.285^{* * *} \\
(0.0528)\end{array}$ & $\begin{array}{l}-0.230 * * * \\
(0.0587)\end{array}$ \\
\hline No. Obs. & 2,459 & 2,477 & 2,329 \\
\hline No. Firms & 349 & 350 & 348 \\
\hline R-squared & 0.059 & 0.069 & 0.061 \\
\hline
\end{tabular}

Notes: This table presents the OLS results. Repurchases is used as a dependent variable. The panel data consist of 385 firms for the period of observation between 1999 and 2014. The total number of observations is 4,797 firm-years, however, this number varies in each model because of missing data. All firm-specific variables are winsorized at $1 \%$ and $99 \%$ to eliminate the influence of outliers. The regressions include time and industry dummies. ***, ** and * indicate statistical significance at the $0.01,0.05$ and 0.10 level, respectively. Robust heteroskedasticity-consistent standard errors are in the parentheses. 
Table 8

Robustness Checks: Fixed-Effects (FE) and the IV-GMM specifications

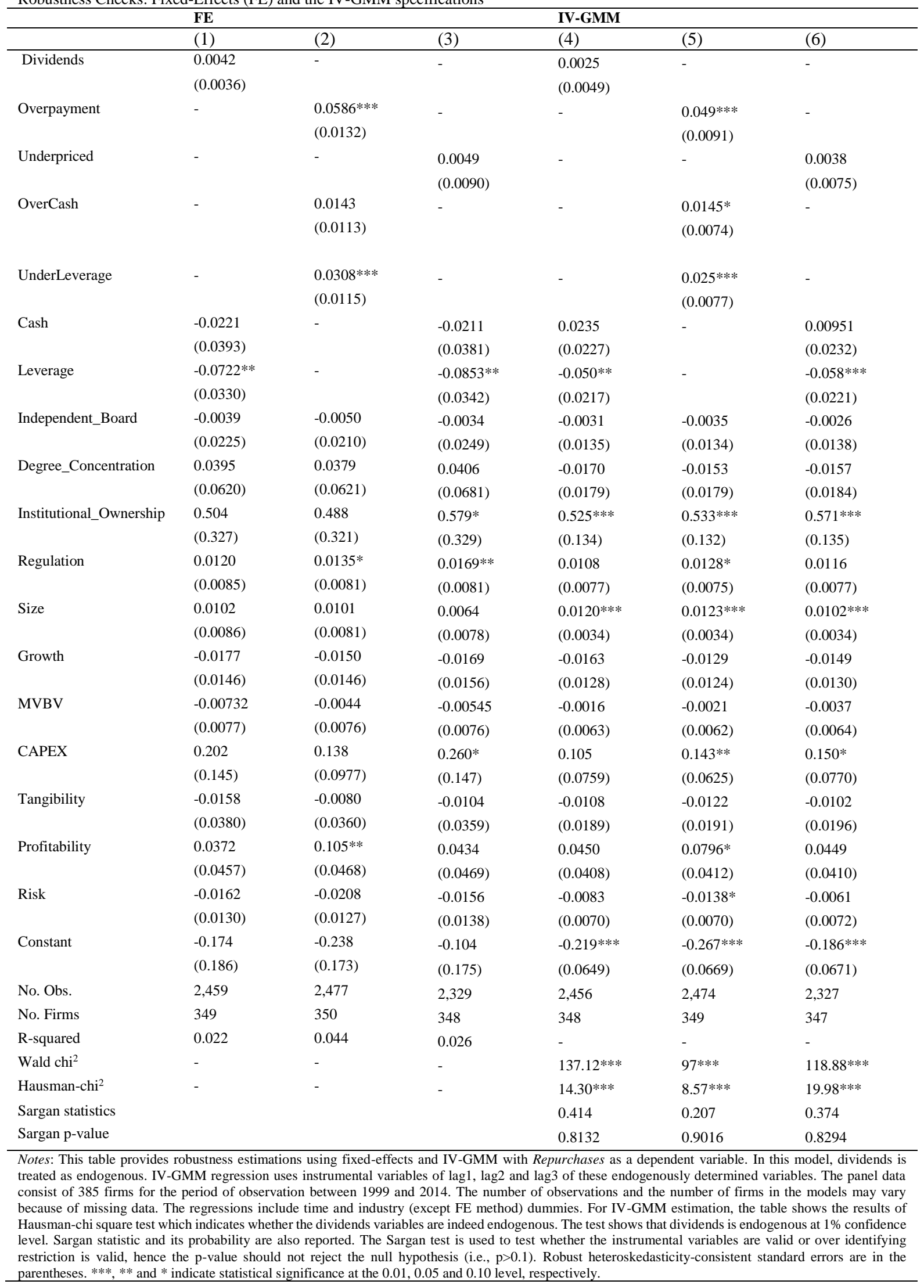


Table 9

Robustness Checks: Sample Selection Bias

\begin{tabular}{|c|c|c|c|c|}
\hline & Expected sign & $\begin{array}{l}\text { Specification } \\
\text { (1) }\end{array}$ & $(2)$ & (3) \\
\hline Dividends & $++/-$ & $\begin{array}{l}-0.0024 \\
(0.0324)\end{array}$ & $\begin{array}{l}- \\
-\end{array}$ & $\begin{array}{l}- \\
-\end{array}$ \\
\hline Overpayment & - & $\begin{array}{l}- \\
-\end{array}$ & $\begin{array}{l}0.601 * * * \\
(0.108)\end{array}$ & - \\
\hline Underpriced & - & $\begin{array}{l}- \\
-\end{array}$ & $\begin{array}{l}- \\
-\end{array}$ & $\begin{array}{l}0.0484 \\
(0.116)\end{array}$ \\
\hline OverCash & + & $\begin{array}{l}- \\
-\end{array}$ & $\begin{array}{l}0.288^{* * * *} \\
(0.110)\end{array}$ & - \\
\hline UnderLeverage & - & $\begin{array}{l}- \\
-\end{array}$ & $\begin{array}{l}0.351 \text { *** } \\
(0.113)\end{array}$ & - \\
\hline Cash & + & $\begin{array}{l}0.627 * * \\
(0.282)\end{array}$ & - & $\begin{array}{l}0.419 \\
(0.300)\end{array}$ \\
\hline Leverage & - & $\begin{array}{l}-1.104 * * * \\
(0.348)\end{array}$ & $\begin{array}{l}- \\
-\end{array}$ & $\begin{array}{l}-1.305^{* * * *} \\
(0.379)\end{array}$ \\
\hline Independent_Board & + & $\begin{array}{l}-0.0639 \\
(0.196)\end{array}$ & $\begin{array}{l}-0.0253 \\
(0.204)\end{array}$ & $\begin{array}{l}-0.0607 \\
(0.203)\end{array}$ \\
\hline Degree_Concentration & + & $\begin{array}{l}-0.506 * * \\
(0.250)\end{array}$ & $\begin{array}{l}-0.586 * * \\
(0.266)\end{array}$ & $\begin{array}{l}-0.508^{*} \\
(0.260)\end{array}$ \\
\hline Institutional_Ownership & + & $\begin{array}{l}2.713^{*} \\
(1.428)\end{array}$ & $\begin{array}{l}3.362 * * \\
(1.433)\end{array}$ & $\begin{array}{l}3.140^{* *} \\
(1.414)\end{array}$ \\
\hline Regulation & + & $\begin{array}{l}0.460 * * * \\
(0.162)\end{array}$ & $\begin{array}{l}0.470 * * * \\
(0.164)\end{array}$ & $\begin{array}{l}0.451 * * * \\
(0.165)\end{array}$ \\
\hline Size & + & $\begin{array}{l}0.312 * * * \\
(0.0425)\end{array}$ & $\begin{array}{l}0.259 * * * \\
(0.0391)\end{array}$ & $\begin{array}{l}0.294 * * * \\
(0.0425)\end{array}$ \\
\hline Growth & - & $\begin{array}{l}-0.131 \\
(0.194)\end{array}$ & $\begin{array}{l}-0.0896 \\
(0.195)\end{array}$ & $\begin{array}{l}-0.0899 \\
(0.199)\end{array}$ \\
\hline MVBV & - & $\begin{array}{l}-0.200 * * \\
(0.0974)\end{array}$ & $\begin{array}{l}-0.128 \\
(0.0952)\end{array}$ & $\begin{array}{l}-0.211 * * \\
(0.102)\end{array}$ \\
\hline CAPEX & - & $\begin{array}{l}1.684 * \\
(0.971)\end{array}$ & $\begin{array}{l}2.723 * * * \\
(0.845)\end{array}$ & $\begin{array}{l}2.288^{* *} \\
(1.008)\end{array}$ \\
\hline Tangibility & + & $\begin{array}{l}-0.448^{*} \\
(0.260)\end{array}$ & $\begin{array}{l}-0.383 \\
(0.273)\end{array}$ & $\begin{array}{l}-0.446 \\
(0.277)\end{array}$ \\
\hline Profitability & + & $\begin{array}{l}0.176 \\
(0.588)\end{array}$ & $\begin{array}{l}0.423 \\
(0.546)\end{array}$ & $\begin{array}{l}0.205 \\
(0.589)\end{array}$ \\
\hline Risk & - & $\begin{array}{l}-0.103 \\
(0.0989)\end{array}$ & $\begin{array}{l}-0.130 \\
(0.102)\end{array}$ & $\begin{array}{l}-0.0598 \\
(0.104)\end{array}$ \\
\hline Lambda & & $\begin{array}{l}-0.163 \\
(3.079)\end{array}$ & $\begin{array}{l}-0.180 \\
(1.903)\end{array}$ & $\begin{array}{l}-0.230 \\
(3.379)\end{array}$ \\
\hline Constant & & $\begin{array}{l}-8.201^{* * *} \\
(0.830)\end{array}$ & $\begin{array}{l}-8.069 * * * \\
(0.795)\end{array}$ & $\begin{array}{l}-7.835 \text { *** } \\
(0.836)\end{array}$ \\
\hline Mills-Lambda $($ Prob $>|z|)$ & & 0.958 & 0.925 & 0.946 \\
\hline Wald Chi ${ }^{2}$ & & $36.64 * * *$ & $61.52 * * *$ & $35.18 * * *$ \\
\hline No. Obs. & & 2,459 & 2,477 & 2,329 \\
\hline Censored observation & & 2361 & 2379 & 2242 \\
\hline Uncensored observation & & 98 & 98 & 87 \\
\hline
\end{tabular}


Table 10

The Effect of Regulatory Changes: Difference-in-Differences analysis (DID)

\begin{tabular}{|c|c|c|c|}
\hline & $(1)$ & $(2)$ & (3) \\
\hline Dividend & $\begin{array}{l}-0.00608^{*} \\
(0.00322)\end{array}$ & 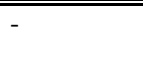 & 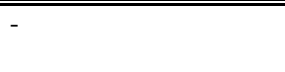 \\
\hline Underpriced & - & - & $\begin{array}{l}0.0116 \\
-0.00798\end{array}$ \\
\hline OverCash & - & $\begin{array}{l}0.00159 \\
(0.0103)\end{array}$ & - \\
\hline UnderLeverage & - & $\begin{array}{l}0.0189 * * \\
(0.00948)\end{array}$ & - \\
\hline Cash & $\begin{array}{l}0.00304 \\
(0.0253)\end{array}$ & - & $\begin{array}{l}-0.00754 \\
-0.0275\end{array}$ \\
\hline Leverage & $\begin{array}{l}-0.0477 * * \\
(0.0197)\end{array}$ & - & $\begin{array}{l}-0.0300 * \\
-0.0167\end{array}$ \\
\hline PostReg & $\begin{array}{l}-0.00854 \\
(0.0181)\end{array}$ & $\begin{array}{l}-0.00228 \\
(0.0161)\end{array}$ & $\begin{array}{l}0.00958 \\
-0.0162\end{array}$ \\
\hline Dividend x PostReg & $\begin{array}{l}0.00707 * \\
(0.00409)\end{array}$ & - & - \\
\hline Underpriced x PostReg & - & - & $\begin{array}{l}-0.01 \\
-0.00979\end{array}$ \\
\hline OverCash x PostReg & - & $\begin{array}{l}0.0112 \\
(0.0120)\end{array}$ & - \\
\hline UnderLeverage x PostReg & - & $\begin{array}{l}0.00315 \\
(0.0112)\end{array}$ & - \\
\hline Cash x PostReg & $\begin{array}{l}0.0577 \\
(0.0458)\end{array}$ & - & $\begin{array}{l}0.0528 \\
-0.0468\end{array}$ \\
\hline Leverage $\mathrm{x}$ PostReg & $\begin{array}{l}-0.0293 \\
(0.0240)\end{array}$ & - & $\begin{array}{l}-0.0603 * * * \\
-0.0228\end{array}$ \\
\hline Independent_Board & $\begin{array}{l}-0.00947 \\
(0.0100)\end{array}$ & $\begin{array}{l}-0.00932 \\
(0.00995)\end{array}$ & $\begin{array}{l}-0.0104 \\
-0.0104\end{array}$ \\
\hline Degree_Concentration & $\begin{array}{l}-0.0231 \\
(0.0183)\end{array}$ & $\begin{array}{l}-0.0218 \\
(0.0186)\end{array}$ & $\begin{array}{l}-0.0225 \\
-0.0192\end{array}$ \\
\hline Institutional_Ownership & $\begin{array}{l}0.5690^{*} \\
(0.298)\end{array}$ & $\begin{array}{l}0.5760^{*} \\
(0.302)\end{array}$ & $\begin{array}{l}0.6210^{* *} \\
-0.312\end{array}$ \\
\hline Size & $\begin{array}{l}0.0137 * * * \\
(0.00502)\end{array}$ & $\begin{array}{l}0.0122 * * * \\
(0.00423)\end{array}$ & $\begin{array}{l}0.0126 * * \\
-0.00497\end{array}$ \\
\hline Growth & $\begin{array}{l}-0.0178 \\
(0.0137)\end{array}$ & $\begin{array}{l}-0.0142 \\
(0.0137)\end{array}$ & $\begin{array}{l}-0.018 \\
-0.0142\end{array}$ \\
\hline MVBV & $\begin{array}{l}0.000798 \\
(0.00609)\end{array}$ & $\begin{array}{l}0.000903 \\
(0.00543)\end{array}$ & $\begin{array}{l}0.00048 \\
-0.00591\end{array}$ \\
\hline CAPEX & $\begin{array}{l}0.0382 \\
(0.0784)\end{array}$ & $\begin{array}{l}0.1190 * \\
(0.0618)\end{array}$ & $\begin{array}{l}0.078 \\
-0.0762\end{array}$ \\
\hline Tangibility & $\begin{array}{l}-0.0139 \\
(0.0193)\end{array}$ & $\begin{array}{l}-0.0158 \\
(0.0183)\end{array}$ & $\begin{array}{l}-0.0112 \\
-0.0189\end{array}$ \\
\hline Profitability & $\begin{array}{l}0.0479 \\
(0.0380)\end{array}$ & $\begin{array}{l}0.0688 \\
(0.0434)\end{array}$ & $\begin{array}{l}0.0501 \\
-0.0367\end{array}$ \\
\hline Risk & $\begin{array}{l}-0.00910 \\
(0.00578)\end{array}$ & $\begin{array}{l}-0.00899 \\
(0.00555)\end{array}$ & $\begin{array}{l}-0.00673 \\
-0.00593\end{array}$ \\
\hline Constant & $\begin{array}{l}-0.2250 * * \\
(0.0947)\end{array}$ & $\begin{array}{l}-0.2310^{* * * *} \\
(0.0800)\end{array}$ & $\begin{array}{l}-0.2260^{* *} \\
-0.0981\end{array}$ \\
\hline $\begin{array}{l}\text { No. Obs. } \\
\text { No. Firms }\end{array}$ & $\begin{array}{l}2,459 \\
349\end{array}$ & $\begin{array}{l}2,477 \\
350\end{array}$ & $\begin{array}{l}2,329 \\
348\end{array}$ \\
\hline Wald $\mathrm{Chi}^{2}$ & 50.85 & 60.69 & 88.04 \\
\hline
\end{tabular}




\section{Appendix}

\section{Table A1}

The definitions of variables

\begin{tabular}{|c|c|c|}
\hline $\begin{array}{l}\text { Variable } \\
\end{array}$ & Definition & Sign \\
\hline "DUM_REP & "Dummy variable: 1 for firms engaging in share repurchases, and 0 otherwise. & NA \\
\hline Repurchases & $\begin{array}{l}\text { Funds used to decrease outstanding common stock or preferred stock divided by total } \\
\text { assets. }\end{array}$ & NA \\
\hline Dividends & $\begin{array}{l}\text { The ratio of total dividends (in Indonesian Rupiah) to total number of shares } \\
\text { outstanding (dividends per share). }\end{array}$ & $+/-$ \\
\hline Overpayment & Dummy variable: 1 when the residual in Eq. (3) is positive, and 0 otherwise. & - \\
\hline OverCash & Dummy variable: 1 when the residual in Eq. (4) is positive, and 0 otherwise. & + \\
\hline UnderLeverage & Dummy variable: 1 when the residual in Eq. (5) is negative, and 0 otherwise. & - \\
\hline Cash & Cash and marketable securities divided by total assets. & + \\
\hline Leverage & The ratio of book value of short-term debt plus long-term debt to total assets. & - \\
\hline \multirow[t]{2}{*}{ Underpriced } & $\begin{array}{l}\text { Dummy variable: } 1 \text { if stock price is underpriced and } 0 \text { otherwise. Following Bonaimé } \\
\text { et al. (2016), the intrinsic value is measured by residual income (RI) method: }\end{array}$ & \\
\hline & $\begin{array}{l}\mathrm{E}_{0}=\mathrm{BV}_{0} \sum_{\mathrm{t}=1}^{\mathrm{n}-1} \frac{\mathrm{RI}_{\mathrm{t}}}{(1+\mathrm{r})^{\mathrm{t}}}+\frac{\mathrm{TV}_{\mathrm{n}}}{(1+\mathrm{r})^{\mathrm{n}-1}} \\
\text { where } E=\text { intrinsic value of equity; } B V=\text { book value of equity; } R I=\text { residual income }= \\
\text { net income minus equity charge, where equity charge is equity capital times cost of } \\
\text { equity; } r=\text { cost of equity; } T V=\text { terminal value. A stock is stated underpriced if } E_{0} \text { is less } \\
\text { than the market capitalization (MCap) or } \mathrm{E}_{0} / \mathrm{MCap}<0 \text {. }\end{array}$ & \\
\hline Independent_Board & $\begin{array}{l}\text { The number of independent commissioners compared to total member of } \\
\text { commissioners. }\end{array}$ & + \\
\hline \multirow[t]{2}{*}{ Degree_Concentration } & $\begin{array}{l}\text { This is based on the Herfindahl-Hirschman Index (HHI). } \\
\text { The degree of concentration is measured as the square root of the sum of five largest }\end{array}$ & \\
\hline & $\begin{array}{l}\text { shareholders. The formula is } \sqrt{\sum_{\mathrm{n}=1}^{5}(\mathrm{xi})^{2}} \text {, where } x \text { is the percentage of shares held by } \\
\text { each shareholder; } i \text { represents each shareholder. }\end{array}$ & + \\
\hline Institutional_Ownership & Percentage of shares held by institutional investors. & + \\
\hline PostReg (Regulation) & Dummy variable: 1 if the year is greater than 2007 and 0 otherwise. & + \\
\hline Size & The natural logarithm of book value of total assets adjusted for inflation. & + \\
\hline Growth & $\begin{array}{l}\text { The current growth measured as percentage change in annual sales. (Salest-Salest- } \\
\text { 1)/Salest-1 }\end{array}$ & - \\
\hline MVBV & $\begin{array}{l}\text { The ratio of market value of assets to book value of assets. Market value of assets equals } \\
\text { the market value of equity plus book value of assets minus book value of equity, all } \\
\text { divided by book value of assets. Book value of equity equals stockholder equity plus } \\
\text { preferred stock less liabilities. }\end{array}$ & \\
\hline CAPEX & The ratio of capital expenditure to book value of assets. & - \\
\hline Tangibility & Ratio of net property, plant and equipment to book value of total assets. & + \\
\hline Profitability & $\begin{array}{l}\text { Return on assets (ROA): the ratio of earnings before interest and tax (EBIT) to total } \\
\text { assets. }\end{array}$ & + \\
\hline CashFlow & $\begin{array}{l}\text { Earnings before interest and tax, but before depreciation and amortization, less interest, } \\
\text { tax, and common dividend, all are divided by total assets. }\end{array}$ & \\
\hline Risk & $\begin{array}{l}\text { CAPM's 5-years beta coefficient calculated by regressing between excess return of } \\
\text { individual stock and excess return on market return. }\end{array}$ & \\
\hline RetainedEarnings & Retained earnings divided by total assets. & + \\
\hline Age & The natural logarithmic transformation of a firm's age since its inception. & + \\
\hline NWC & Net working capital minus cash over total assets. & + \\
\hline $\mathrm{R} \& \mathrm{D}$ & Research and development expenses over sales. & - \\
\hline IndustryLeverage & Median leverage of firms within the same industry. & + \\
\hline StockMarket & The growth of the stock market index. & + \\
\hline DebtMarket & Net interest rate $=$ Annual interest rate $(1-$ corporate tax $)$. & - \\
\hline Macroeconomy & Gross domestic product (GDP) growth in percentage. & + \\
\hline
\end{tabular}

